\title{
Early antipsychotic treatment in juvenile rats elicits long-term alterations to the adult serotonin receptors
}

This article was published in the following Dove Press journal:

Neuropsychiatric Disease and Treatment

\author{
Michael De Santis ${ }^{1,2}$ \\ Xu-Feng Huang ${ }^{2}$ \\ Chao Deng ${ }^{1,2}$
}

'Antipsychotic Research Laboratory, Illawarra Health and Medical Research Institute, University of Wollongong, Wollongong, NSW, Australia; ${ }^{2}$ School of Medicine, University of Wollongong, Wollongong, NSW, Australia
Correspondence: Chao Deng Antipsychotic Research Laboratory, Illawarra Health and Medical Research Institute, University of Wollongong, Northfields Avenue, Wollongong, NSW 2522, Australia

Tel $+6 \mid 2$ 422। 4934

Fax +6I 242218130

Email chao@uow.edu.au
Background: Antipsychotic drug (APD) prescription/use in children has increased significantly worldwide, despite limited insight into potential long-term effects of treatment on adult brain functioning. While initial long-term studies have uncovered alterations to behaviors following early APD treatment, further investigations into potential changes to receptor density levels of related neurotransmitter (NT) systems are required.

Methods: The current investigation utilized an animal model for early APD treatment with aripiprazole, olanzapine, and risperidone in male and female juvenile rats to investigate potential long-term changes to the adult serotonin (5-HT) NT system. Levels of 5-HT 1 , $5-\mathrm{HT}_{2 \mathrm{~A}}$, and $5-\mathrm{HT}_{2 \mathrm{C}}$ receptors were measured in the prefrontal cortex $(\mathrm{PFC})$, caudate putamen $(\mathrm{CPu})$, nucleus accumbens (NAc), and hippocampus via Western Blot and receptor autoradiography.

Results: In the male cohort, long-term changes to $5-\mathrm{HT}_{2 \mathrm{~A}}$ and $5-\mathrm{HT}_{2 \mathrm{C}}$ receptors were found mostly across hippocampal and cortical brain regions following early aripiprazole and olanzapine treatment, while early risperidone treatment changed 5- $\mathrm{HT}_{1 \mathrm{~A}}$ receptor levels in the NAc and PFC. Lesser effects were uncovered in the female cohort with aripiprazole, olanzapine and risperidone to alter $5-\mathrm{HT}_{1 \mathrm{~A}}$ and $5-\mathrm{HT}_{2 \mathrm{~A}}$ receptors in NAc and hippocampal brain regions, respectively.

Conclusion: The results of this study suggest that early treatment of various APDs in juvenile rats may cause gender and brain regional specific changes in $5-\mathrm{HT}_{2 \mathrm{~A}}$ and $5-\mathrm{HT}_{2 \mathrm{C}}$ receptors in the adult brain.

Keywords: antipsychotic drug, serotonin, risperidone, olanzapine, aripiprazole, development, juvenile

\section{Introduction}

Antipsychotic drug (APD) prescription and use is rapidly increasing globally, despite a lack of knowledge on the safety and efficacy of APD use on the developing brain. ${ }^{1-10}$ Second-generation APDs including aripiprazole, olanzapine, and risperidone are currently commonly being prescribed (mostly off-label) for the treatment of a variety of childhood disorders from mental illnesses, including depression and childonset schizophrenia, ${ }^{5,11,12}$ to various behavioral disorders, including autism spectrum disorder. ${ }^{13-15}$

While APDs are known to elicit their therapeutic effects predominantly through a strong affinity and subsequent antagonistic mechanism of action on both the dopamine (DA) $\mathrm{D}_{2}$ and serotonin (5-HT) 5- $\mathrm{HT}_{1 \mathrm{~A}}$ and 5- $\mathrm{HT}_{2 \mathrm{~A} / 2 \mathrm{C}}$ receptors, ${ }^{16-22}$ both the dopaminergic and serotonergic neurotransmitter (NT) systems have been proven to undergo, and be heavily involved in, numerous critical neurodevelopmental processes during 
the childhood/adolescent period. ${ }^{19,23-29}$ Specifically, 5-HT is known to play an early significant and concentration-dependent trophic role in neural development and neurite growth ${ }^{8,26,30-33}$ and then also undergo specific phases of development as a NT system (eg, synaptogenesis and regressive elimination). ${ }^{8,31}$

Subsequently, there is the potential that early insult/use of potent APDs at this critical time of neurodevelopment may have the ability to cause long-term alterations to the functionality of the NT systems, including that of 5-HT, in a manner that precedes normal brain functioning. . $^{87,34,35}$ With alterations to the 5-HT NT system previously linked to changes in both behavioral attributes (including locomotor, anxiety, and depressive-like behaviors) and furthermore negatively correlated to dopamine NT functioning, ${ }^{36-38}$ prescription and use of APDs during the critical neurodevelopmental time period have the potential to lead to long-term deficits in brain functioning. . $^{10,35,39}$

Although current clinical investigations have found some benefits to childhood/adolescent APD use in the treatment of the symptomology of various mental illnesses over a shortterm time period (1-2 months) and a time period of up to 6 months, ${ }^{40-42}$ the potential for the use of potent APDs to cause long-term alterations to adult brain functioning, especially in a clinical setting, is still mostly unknown. ${ }^{19,43,44}$

Previously completed animal studies investigating the effects of juvenile APD use on the developing brain, including previous studies completed in our laboratory, have found that early treatment of up to 4 weeks can result in various significant long-term changes to behavioral attributes ${ }^{39}$ and immediate alterations to NT pathways including the 5-HT NT system. ${ }^{45,46}$ While investigations into the distribution/ density of various NT receptor subtypes, including 5-HT ${ }_{1 \mathrm{~A}}$, $5-\mathrm{HT}_{2 \mathrm{~A}}$, and 5- $\mathrm{HT}_{2 \mathrm{C}}$ receptors, have found various immediate alterations following short-term APD treatment, ${ }^{44,45,47}$ studies investigating the long-term effects of early APD treatment have been found to be limited to the DA NT system. ${ }^{19,35,48}$

The present study was subsequently conducted in order to investigate the long-term effects of juvenile APD use with aripiprazole, olanzapine, and risperidone on the adult 5-HT NT system in both male and female rats. Specifically, investigations into adult brain levels of $5-\mathrm{HT}_{1 \mathrm{~A}}, 5-\mathrm{HT}_{2 \mathrm{~A}}$, and $5-\mathrm{HT}_{2 \mathrm{C}}$ receptors were investigated in cortical, striatal, and hippocampal brain regions via Western Blot and/or receptor autoradiography experiments.

\section{Materials and methods}

\section{Animals and housing}

Timed pregnant Sprague Dawley rats were obtained at gestation day 16 from the Animal Resource Centre (Perth, WA,
Australia) and housed in individual cages under environmentally controlled conditions $\left(22^{\circ} \mathrm{C}\right.$, light cycle from 7 am to $7 \mathrm{pm}$ and dark cycle from $7 \mathrm{pm}$ to $7 \mathrm{am})$. Each was allowed ad libitum access to standard laboratory chow diet $(3.9 \mathrm{kcal} / \mathrm{g}$ : $10 \%$ fat, $74 \%$ carbohydrate, and $16 \%$ protein) and water. The day of birth was considered postnatal day (PD) 0 . Pups were sexed on PD14, and then, 96 rats (48 males and 48 females) were weaned on PD20. Rats were housed in individual rat cages with top wire lids, in which they were able to smell and see each other through the lids.

\section{Drug treatment groups}

After weaning and prior to the commencement of drug treatment, all animals were trained for self-administration by feeding them cookie dough $(0.3 \mathrm{~g})$ without drugs two times per day for PD18-21. Rats were then randomly assigned to one of the four experimental groups per gender on PD21 ( $n=12$ /group): 1) aripiprazole (Otsuka, Tokyo, Japan), 2) olanzapine (Eli Lilly, Indianapolis, IN, USA), 3) risperidone (Apotex, Toronto, ON, Canada), and 4) control (vehicle). Drug treatment was carried out in juvenile rats from PD22-50, a time period equivalent to the childhood/adolescent phase in humans. ${ }^{26}$ In order to replicate a clinical setting, a staggered drug treatment pattern was used, where lower APD dosages are slowly increased to a final dosage amount. ${ }^{49}$ Specifically, APD doses were initiated on PD22 at $0.2 \mathrm{mg} / \mathrm{kg}$ for aripiprazole, $0.25 \mathrm{mg} / \mathrm{kg}$ three times per day for olanzapine, and $0.05 \mathrm{mg} / \mathrm{kg}$ three times per day for risperidone and were increased in three steps over the first 7 days of the 4-week treatment period to achieve a final dose on PD2 8 of $1 \mathrm{mg} / \mathrm{kg}$ three times per day for aripiprazole, $1 \mathrm{mg} / \mathrm{kg}$ three times per day for olanzapine, and $0.3 \mathrm{mg} / \mathrm{kg}$ three times per day for risperidone. Drug treatment was administered orally to each drug treatment group via mixing cookie dough powder (containing cornstarch $37 \%$, sucrose $37 \%$, gelatine $17 \%$, and casein $9 \%$ ) with a small amount of distilled water until even in consistency. All animals were individually observed for the duration of each treatment to ensure that they completely consumed the cookie dough pellet and thus received a full dosage. Animals in the control group also received an equivalent pellet without the drug. In consideration of a shorter half-life of APDs in rats, and to ensure a consistently high drug concentration in replication of the clinical scenario of oral administration once per day,$^{50} \mathrm{APDs}$ were administered three times per day (at 7,2, and $10 \mathrm{~h}$ ) with $8 \pm 1$ hour intervals. The proposed dosages are translated from a clinical setting and within the recommended dosage ranges for the psychiatric treatment of pediatric patients. Dosage calculations are based on the body surface area formula for dosage translation between humans and 
rats in the US Food and Drug Administration guideline for clinical trials..$^{42,49,51,52}$ The relevant human equivalent dose (HED) is therefore calculated by the following formula: animal dose $(\mathrm{mg} / \mathrm{kg}) \times$ animal Km (6)/human child $\mathrm{Km}(25) \times$ body weight (Km factor, body weight $(\mathrm{kg})$ divided by body surface area $\left(\mathrm{m}^{2}\right)$, is used to convert the $\mathrm{mg} / \mathrm{kg}$ dose to a $\mathrm{mg}$ / $\mathrm{m}^{2}$ dose). Therefore, for an adolescent with an average weight of $40 \mathrm{~kg}$, the utilized dosages for aripiprazole ( $1 \mathrm{mg} / \mathrm{kg}$ in rats) and olanzapine (1 $\mathrm{mg} / \mathrm{kg}$ in rats) equals to a clinical dosage of $9.6 \mathrm{mg}$, while risperidone $(0.3 \mathrm{mg} / \mathrm{kg})$ equals to a clinical dosage of $2.88 \mathrm{mg}$, all within a clinically relevant range for adolescent patients. Previous reports have demonstrated that at this dosage amount, aripiprazole drug treatment reaches $>90 \% \mathrm{DA} \mathrm{D}_{2}$ receptor occupancy rates in the rat brain, ${ }^{53}$ while olanzapine and risperidone reach $65 \%-80 \% \mathrm{DA} \mathrm{D}_{2}$ receptor occupancy rates. ${ }^{54,55}$ These dosage amounts have also been shown to be physiologically and behaviorally effective in our laboratory, with similar dosages seen to induce weight gain and changes in hypothalamic neuropeptide $\mathrm{Y}$ expression in adolescent rats, ${ }^{56}$ while immediate alterations to both DA receptor and 5-HT receptor binding have been reported in juvenile rats. ${ }^{45}$ All experimental procedures were approved by the Animal Ethics Committee, University of Wollongong, Wollongong, NSW, Australia (AE 12/20) and complied with Australian Code of Practice for the Care and Use of Animals for Scientific Purpose (2004).

\section{Histological procedures}

After a maturation period where all animals were monitored regularly and allowed to mature (PD51-105), all rats were sacrificed on PD106 via carbon dioxide asphyxiation. Euthanasia was completed between 9 am and 11.30 am to minimize the potential circadian-induced variation of protein expression. Brain tissue was removed immediately following euthanasia, frozen in liquid nitrogen, and stored at $-80^{\circ} \mathrm{C}$ until analysis. Six brains from each drug treatment group $(n=12)$ were then randomly assigned for Western Blot analyses, and the remaining six brains from each treatment group were then used for receptor autoradiography experiments. Brain regions involved in both serotonergic signaling and the therapeutic actions of APDs, including the prefrontal cortex (PFC), caudate putamen $(\mathrm{CPu})$, nucleus accumbens (NAc), and hippocampus, were dissected in order to detect 5-HT receptor levels.

\section{Microdissection (Western Blot analyses)}

Tissue from aforementioned brain regions to be used for Western Blot analysis was collected using microdissection puncture techniques, following a standard procedure in our laboratory. ${ }^{57-60}$ Briefly, $500 \mu \mathrm{m}$ thick sections were cut at $-14^{\circ} \mathrm{C}$ using a cryostat (Leica CM1850; Leica Microsystems, Wetzler, Germany) and collected bilaterally using a microdissection puncher on glass slides.

\section{Receptor autoradiography}

Tissue from brains selected for receptor autoradiography were collected via coronally dissected sections at $-18^{\circ} \mathrm{C}$ into $14 \mu \mathrm{m}$ using a cryostat (Leica CM1850). Once dissected, sections were thaw-mounted onto poly-L-lysine (Sigma-Aldrich Co., St Louis, MO, USA)-coated glass slides and stored at $-20^{\circ} \mathrm{C}$. A set of sections from each animal were stained with the $0.5 \%$ cresyl violet solution (Nissl staining) and used to confirm the identification of anatomical structures.

\section{Western Blot analyses}

Tissues obtained from individual rats were homogenized in ice-cold homogenizing buffer $(9.8 \mathrm{~mL}$ of NP-40 cell lysis buffer; Thermo Fisher Scientific, Waltham, MA, USA; $100 \mu \mathrm{L}$ of $\beta$-glycerophosphate; $50 \mathrm{mM}$; Thermo Fisher Scientific; $33.3 \mu \mathrm{L}$ of phenylmethane sulfonyl fluoride; $0.3 \mathrm{M}$; Sigma-Aldrich Co.; and $100 \mu \mathrm{L}$ of Protease Inhibitor Cocktail; Sigma-Aldrich Co.). All samples were then centrifuged, with the supernatant solution collected and stored at $-80^{\circ} \mathrm{C}$ until required.

DCTM Protein Assays (\#500-0114; Bio-Rad Laboratories Inc., Hercules, CA, USA) were completed at $A_{750 \mathrm{~nm}}$ to spectrophotometrically quantify total protein concentrations. A range of sample protein concentrations were pretested in each region $(2,2.5,4,5,6,7.5,8$, and $10 \mu \mathrm{g})$. A total of $10 \mu \mathrm{g}$ of protein was selected for $\mathrm{PFC}, \mathrm{CPu}$, and NAc regions, while $8 \mu \mathrm{g}$ of protein was selected for the hippocampus as it best fitted the linear range of signal detection for all tested antibodies. Homogenized brain samples containing the aforementioned microgram concentration of protein were then first heated at $95^{\circ} \mathrm{C}$ in the loading buffer $(950 \mu \mathrm{L}$ of Laemmli buffer; Bio-Rad Laboratories Inc.; and $50 \mu \mathrm{L}$ of $\beta$-mercaptoethanol; SigmaAldrich Co.) for 5 minutes to denature the protein, then placed on ice, and centrifuged for 2 minutes at $4^{\circ} \mathrm{C}$. The samples were then loaded into $4 \%-20 \%$ Criterion $^{\mathrm{TM}} \mathrm{TGX}^{\mathrm{TM}}$ Precast Gels (Bio-Rad Laboratories Inc.) and underwent electrophoresis in sodium dodecyl sulfate polyacrylamide gel electrophoresis (SDS PAGE) running buffer (100 mL of $10 \times$ SDS-PAGE running buffer; Bio-Rad Laboratories Inc.; and $900 \mathrm{~mL}$ of distilled water) at $140 \mathrm{~V}$ for 70 minutes. Proteins on the gels were then transferred electrophoretically using the Bio-Rad Midi Format 1-D Electrophoresis Systems onto a polyvinylidene difluoride (PVDF) membrane (Bio-Rad Laboratories Inc.) in ice-cold transfer buffer (150 mL of 10× tris/glycine buffer; Bio-Rad Laboratories Inc.; $300 \mathrm{~mL}$ of cold methanol, and 1,050 mL 
of distilled water) at $100 \mathrm{~V}$ for 1 hour. In order to detect the proteins of interest, PVDF membranes were incubated in tris-buffered saline-Tween (TBST) (Sigma-Aldrich Co.) solution containing 5\% Blotting-Grade Blocker (nonfat dry milk powder) (Bio-Rad Laboratories Inc.) for 1 hour at room temperature (RT). Membranes were then incubated overnight with the primary antibody, including 5-HT ${ }_{1 \mathrm{~A}}(1: 2,000$; \#ab85615; Abcam, Cambridge, UK), 5-HT (1: (1,000; \#sc-50397; Santa Cruz Biotechnology Inc., Dallas, TX, USA), and 5-HT ${ }_{2 \mathrm{C}}$ (1:1,000; \#sc-15081; Santa Cruz Biotechnology Inc.), diluted in TBST buffer containing either $1 \%$ bovine serum albumin (BSA) $\left(5-\mathrm{HT}_{1 \mathrm{~A}}\right)$ or $1 \%$ nonfat dry milk powder $\left(5-\mathrm{HT}_{2 \mathrm{~A}}\right.$ and $\left.5-\mathrm{HT}_{2 \mathrm{C}}\right)$. Membranes were either washed three times with TBST for 5 minutes $\left(5-\mathrm{HT}_{1 \mathrm{~A}}\right.$ and $\left.5-\mathrm{HT}_{2 \mathrm{~A}}\right)$ and then incubated with horseradish peroxidase (HRP)-conjugated goat antirabbit secondary antibody for 1 hour at RT $\left(5-\mathrm{HT}_{1 \mathrm{~A}}-1: 5,000\right.$ and $5-\mathrm{HT}_{2 \mathrm{~A}}-1: 3,000$; EMD Millipore, Billerica, MA, USA) or washed three times for 20 minutes $\left(5-\mathrm{HT}_{2 \mathrm{C}}\right)$ and then incubated with HRP-conjugated donkey antigoat secondary antibody for 45 minutes at RT $\left(5-\mathrm{HT}_{2 \mathrm{C}}-1: 2,000\right.$; Abcam). Secondary antibodies were diluted in TBST buffer containing either $1 \%$ BSA $\left(5-\mathrm{HT}_{1 \mathrm{~A}}\right)$ or $1 \%$ nonfat dry milk powder $\left(5-\mathrm{HT}_{2 \mathrm{C}}\right.$ and $\left.5-\mathrm{HT}_{2 \mathrm{~A}}\right)$. Three TBST washes then followed secondary antibody incubation, and proteins of interest were visualized using the Classico Western horseradish peroxidase (HRP) substrates (EMD Millipore) and Amersham Hyperfilm ECL (GE Healthcare Life Sciences, Wauwatosa, WI, USA). Membranes were then re-probed with mouse antiactin polyclonal antibody (1:10,000, \#MAB1501; EMD Millipore) and HRP-conjugated rabbit antimouse secondary antibody (1:3,000, \#7076; Cell Signaling Technology, Danvers, MA, USA).

Immunoreactive signals were quantified using the GS-800 image densitometry and Quantity One software (Bio-Rad Laboratories Inc.), and the values were corrected based on their corresponding actin levels. For $5-\mathrm{HT}_{1 \mathrm{~A}}$, the band at $\sim 62 \mathrm{kDa}$ was detected and quantified, ${ }^{61}$ while for $5-\mathrm{HT}_{2 \mathrm{~A}}$, the band at $\sim 55 \mathrm{kDa}$ was detected and quantified. ${ }^{62,63}$ Furthermore, for $5-\mathrm{HT}_{2 \mathrm{C}}$, a band at $\sim 55 \mathrm{kDa}$ was detected and quantified. ${ }^{64}$ The $\beta$-actin protein was quantified at $46 \mathrm{kDa}$. Western Blot gels were arranged by gender, in which each gel contained 24 samples (six rats/group $\times$ four treatments [ie, three APDs and one vehicle] $\times$ one gender). In order to control for variability, all samples were run in duplicate at second gels at the same sample arrangement and the values of each drug treatment group and control corrected based on their corresponding actin levels. Samples from male and female rats were run in different gels. All results were normalized by taking the value of the vehicle group of each gender as $100 \%$ to obtain a comparative value.

\section{Receptor autoradiography and quantification}

Experimental procedures for $5-\mathrm{HT}_{2 \mathrm{~A}}$ binding autoradiography were based on those completed and reported previously. ${ }^{45,65-67}$ $5-\mathrm{HT}_{1 \mathrm{~A}}$ and $5-\mathrm{HT}_{2 \mathrm{C}}$ binding autoradiography was also completed; however, binding results were too low and thus discounted from further analysis.

\section{5- $\mathrm{HT}_{2 \mathrm{~A}}$ receptor binding procedures}

Brain sections for $5-\mathrm{HT}_{2 \mathrm{~A}}$ receptor binding were thawed at RT and then preincubated in $170 \mathrm{mM}$ tris buffer ( $\mathrm{pH} 7.4$ ) for 15 minutes. Slides with sections were then incubated for 2 hours with $2 \mathrm{nM}\left[{ }^{3} \mathrm{H}\right]$ Ketanserin (specific activity: $47.3 \mathrm{Ci}$ / mmol; PerkinElmer Inc., Waltham, MA, USA) in $170 \mathrm{mM}$ tris buffer at RT to determine total binding. Nonspecific binding was determined with the addition of $2 \mu \mathrm{M}$ Spiperone (Sigma-Aldrich Co.) to subsequent sections. Following incubation, sections were washed four times for 2 minutes in ice-cold buffer, dipped in ice-cold distilled water, and then air dried. ${ }^{66,67}$

\section{Quantification}

Following the completion of receptor binding experiments, all slides were exposed to Amersham Hyperfilm ECL for 2-3 months, along with autoradiographic standards $\left(\left[{ }^{3} \mathrm{H}\right]\right.$ microscales from Amersham), in X-ray film cassettes. Quantitative analysis of binding images was conducted following the relevant exposure time, using the Multi-Analyst image analysis system (Bio-Rad Laboratories Inc.), connected to a GS-800 Imaging Densitometer (Bio-Rad Laboratories Inc.). Optical density measurement was then converted into femtomoles of $\left[{ }^{3} \mathrm{H}\right]$ ligand per milligram of tissue equivalent (TE) by comparing to the standard. Specific binding was calculated by subtracting nonspecific binding from total binding. A set of sections from each animal were stained with the $0.5 \%$ cresyl violet solution (Nissl staining), for the purpose of confirmation of anatomical structures. Specific brain regions in this project were identified by reference to the Nissl-stained sections, along with a standard rat brain atlas. ${ }^{68}$

\section{Statistical analysis}

Statistical analysis of collected data was completed with the use of SPSS software (Windows Version 19.0; IBM Corporation, Armonk, NY, USA). Distribution of data was examined through the Kolmogorov-Smirnov test. All normally distributed data were also analyzed by two-way analysis of variance (ANOVA) (gender $\times$ treatment). Male and female data sets were then also analyzed separately by one-way ANOVA, followed by post hoc Dunnett's tests for 
multiple comparisons between the treatment groups. Data that were not distributed normally were analyzed via the nonparametric Mann-Whitney $U$ test. All data were analyzed per investigated brain region. The data were expressed as mean \pm standard error of the mean (SEM). Statistical significance was accepted when $P<0.05$.

\section{Results}

\section{Long-term effects of adolescent APD treatment on $5-\mathrm{HT}_{I A}$ receptor levels}

A significant effect of treatment on $5-\mathrm{HT}_{1 \mathrm{~A}}$ receptor protein expression was found in the PFC $\left(F_{3,45}=4.973, P<0.01\right)$ and NAc $\left(F_{3,44}=3.791, P<0.02\right)$, while a significant effect of gender was also observed in the NAc $\left(F_{1,44}=13.584\right.$, $P<0.01)$. Furthermore, a significant interaction between the two factors was found in the $\mathrm{CPu}\left(F_{3,46}=2.860, P=0.050\right)$ and a trend toward a significant interaction was found in the NAc $\left(F_{3,44}=2.559, P=0.070\right)$. Post hoc analysis uncovered that early risperidone treatment decreased $5-\mathrm{HT}_{1 \mathrm{~A}}$ expression in the PFC $(-23.8 \%, P<0.02)$ when compared with the control (Figures $1 \mathrm{~A}^{\prime}$ and $\mathrm{A}^{\prime \prime}$ and $\underline{\mathrm{S} 1}$ ). In the male cohort, early APD treatment had a significant effect on the expression of $5-\mathrm{HT}_{1 \mathrm{~A}}$ receptors in the NAc $\left(F_{3,22}=5.091, P<0.01\right)$ of adult rats. Further analysis revealed that early risperidone treatment trended to significantly decrease $5-\mathrm{HT}_{1 \mathrm{~A}}$ receptor expression in the NAc $(-7.0 \%, P=0.081)$ (Figures 1 and $\underline{\mathrm{S} 1})$. Analysis of the female cohort found trends toward significant effects of early APD treatment in both $\mathrm{CPu}\left(F_{3,22}=2.853, P=0.065\right)$ and NAc $\left(F_{3,20}=2.695, P=0.079\right)$. Post hoc analysis revealed that early aripiprazole treatment decreased $5-\mathrm{HT}_{1 \mathrm{~A}}$ receptor expression in the NAc $(-16.6 \%, P=0.054)$ when compared with the control group. No significant alterations were uncovered in the $\mathrm{CPu}$ (Figures $1 \mathrm{~B}^{\prime}$ and $\mathrm{B}^{\prime \prime}$ and $\underline{\mathrm{S} 1}$ ) or hippocampus (Figures $1 \mathrm{D}^{\prime}$ and $\mathrm{D}^{\prime \prime}$ and $\underline{\mathrm{S} 1}$ ) of treated animals in comparison to the control, across either gender.

\section{Long-term effects of adolescent APD treatment on $5-\mathrm{HT}_{2 \mathrm{~A}}$ receptor levels}

Two-way ANOVA tests (gender $\times$ treatment) revealed a significant effect of treatment on $5-\mathrm{HT}_{2 \mathrm{~A}}$ receptor protein expression levels in the hippocampus $\left(F_{3,45}=4.913, P<0.01\right)$, while a significant effect of gender was found in the hippocampus $\left(F_{1,45}=17.745, P<0.001\right)$ and $\mathrm{CPu}\left(F_{1,46}=4.541, P<0.05\right)$. Additionally, a significant interaction between the factors was uncovered in the hippocampus $\left(F_{3,45}=3.340, P<0.05\right)$ and $\operatorname{PFC}\left(F_{3,46}=3.972, P<0.02\right)$. Analysis of the male cohort via one-way ANOVA (treatment) uncovered a significant effect of early APD treatment on $5-\mathrm{HT}_{2 \mathrm{~A}}$ receptor expression in the NAc $\left(F_{3,22}=3.378, P<0.05\right)$, and hippocampus
$\left(F_{3,22}=4.054, P<0.05\right)$. Furthermore, a trend to significant effect was also discovered in the $\operatorname{PFC}\left(F_{3,22}=3.035, P=0.054\right)$. Post hoc analysis discovered that aripiprazole treatment was found to decrease $5-\mathrm{HT}_{2 \mathrm{~A}}$ receptor levels in the PFC $(-78.0 \%, P=0.081)$ upon comparison to the control group. In the female cohort, one-way ANOVA found a significant effect of early APD treatment on $5-\mathrm{HT}_{2 \mathrm{~A}}$ expression in the PFC $\left(F_{3,22}=3.233, P<0.05\right)$ (Figures $2 \mathrm{~A}^{\prime}$ and $\mathrm{A}^{\prime \prime}$ and $\underline{\mathrm{S} 2}$ ) and hippocampus $\left(F_{3,21}=4.738, P<0.02\right.$ ) (Figures $2 \mathrm{D}^{\prime}$ and $\mathrm{D}^{\prime \prime}$ and $\left.\underline{\mathrm{S} 2}\right)$. Further analysis via post hoc tests discovered decreases to $5-\mathrm{HT}_{2 \mathrm{~A}}$ receptor expression in the hippocampus following early olanzapine $(-62.4 \%, P<0.01)$ treatment. No significant changes in the expression of $5-\mathrm{HT}_{2 \mathrm{~A}}$ receptors were uncovered in the $\mathrm{CPu}$ (Figures $2 \mathrm{~B}^{\prime}$ and $\mathrm{B}^{\prime \prime}$ and $\underline{\mathrm{S}}$ ) or NAc (Figures $2 \mathrm{C}^{\prime}$ and $\mathrm{C}^{\prime \prime}$ and $\underline{\mathrm{S} 2}$ ) of APD animals in comparison to the control, across both male and female cohorts.

Examples of $\left[{ }^{3} \mathrm{H}\right]$ Ketanserin binding to $5-\mathrm{HT}_{2 \mathrm{~A}}$ are presented in Figure 3. Detected levels of $5-\mathrm{HT}_{2 \mathrm{~A}}$ in the $\mathrm{CPu}$ of females and males, however, were discounted, as expression was too low for accurate quantification. Analysis via two-way ANOVA (gender $\times$ treatment) found a significant effect of early APD treatment on the expression of $5-\mathrm{HT}_{2 \mathrm{~A}}$ receptors in the hippocampus $\left(F_{3,41}=2.106, P<0.01\right)$, along with a significant interaction between the two factors $\left(F_{3,41}=1.228\right.$, $P<0.05)$. A trend to significant effect of treatment was also uncovered in the PFC of rats $\left(F_{3,43}=4.004, P=0.079\right)$. Post hoc analysis revealed that early treatment with both aripiprazole $(-49.0 \%, P<0.02)$ and risperidone $(-51.1 \%, P<0.01)$ significantly decreased $5-\mathrm{HT}_{2 \mathrm{~A}}$ expression in the hippocampus in comparison to the control. When subsequently divided by gender, analysis of the male cohort demonstrated a significant effect of early APD treatment on $5-\mathrm{HT}_{2 \mathrm{~A}}$ receptor expression in the PFC $\left(F_{3,21}=4.010, P<0.05\right)$ and hippocampus $\left(F_{3,21}=6.274, P<0.01\right)$. Further analysis via post hoc revealed that early treatment with aripiprazole decreased $5-\mathrm{HT}_{2 \mathrm{~A}}$ binding in the PFC $(-44.3 \%, P=0.064)$ and hippocampus $(-48.8 \%, P<0.05)$. Similar decreases were also observed following risperidone treatment in the PFC $(-60.2 \%, P<0.02)$ and hippocampus $(-69.5 \%, P<0.01)$ and olanzapine treatment in the hippocampus $(-44.7 \%, P=0.063)$. No significant effects were found in the female cohort between the APD treatment group and control.

\section{Long-term effects of adolescent APD treatment on $5-\mathrm{HT}_{2 \mathrm{C}}$ receptor levels} Analysis of $5-\mathrm{HT}_{2 \mathrm{C}}$ expression via two-way ANOVA (gender $\times$ treatment) uncovered a significant effect of treatment on $5-\mathrm{HT}_{2 \mathrm{C}}$ receptor protein expression in the $\mathrm{PFC}$ $\left(F_{3,44}=4.286, P<0.02\right)$ and hippocampus $\left(F_{3,45}=10.791\right.$, 

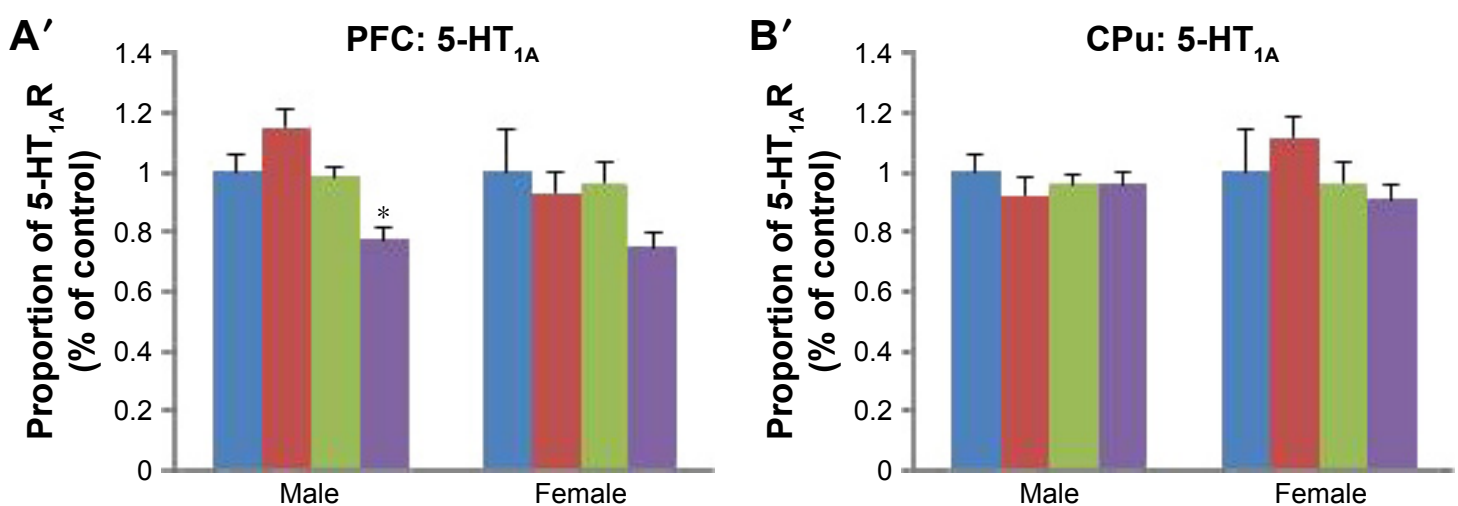

\section{$\square$ Control aripiprazole $\square$ Olanzapine $\square$ Risperidone}

$A^{\prime \prime}$

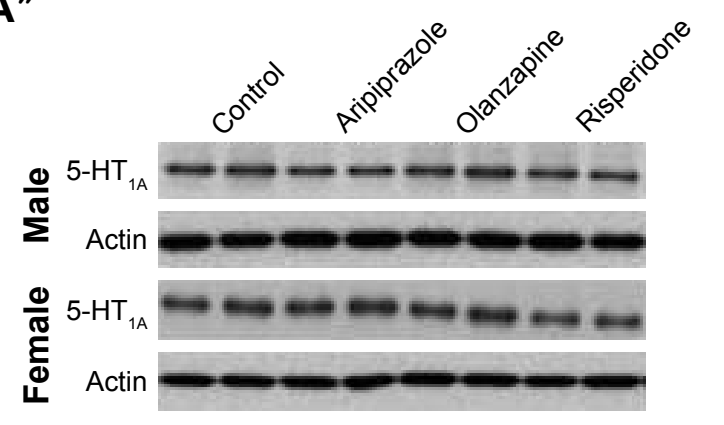

$C^{\prime}$

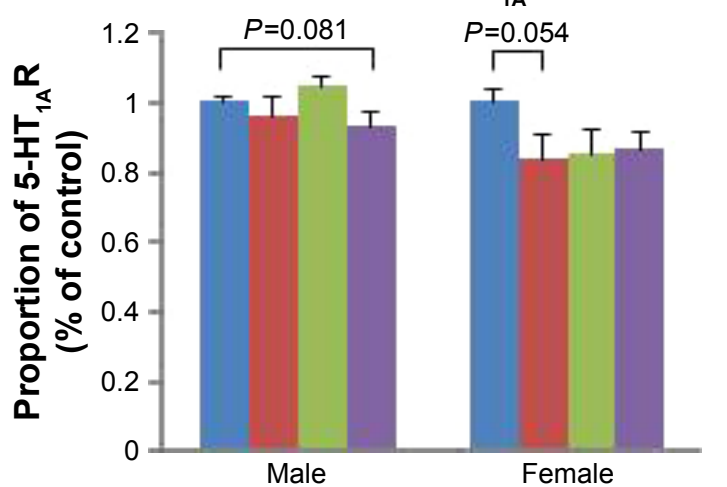

B"

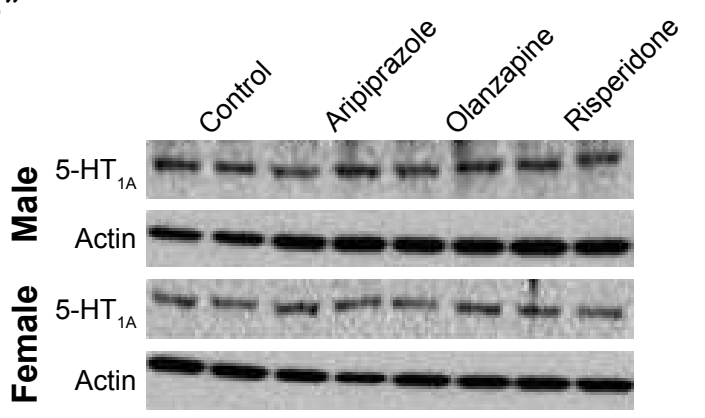

$D^{\prime}$

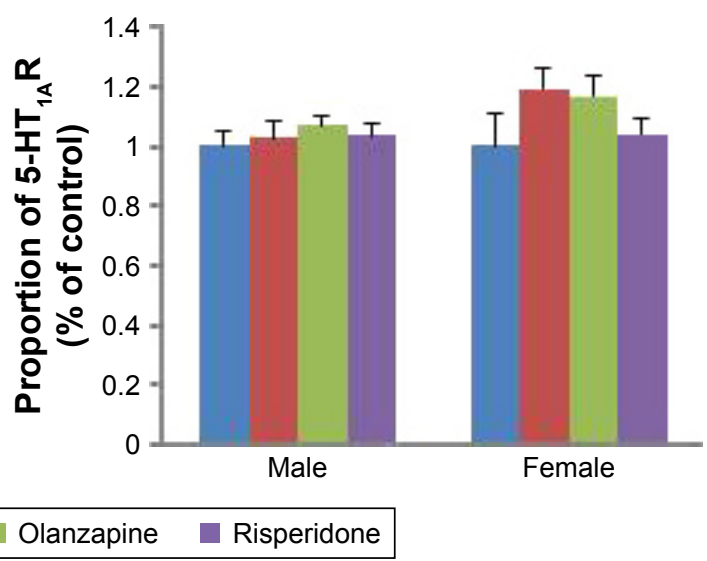

$C^{\prime \prime}$

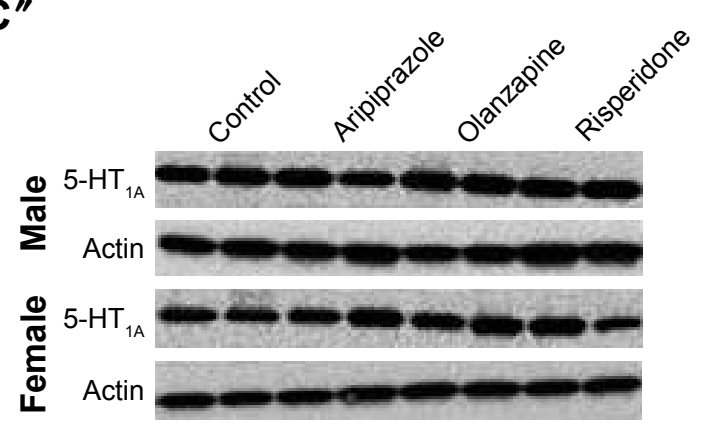

$D^{\prime \prime}$

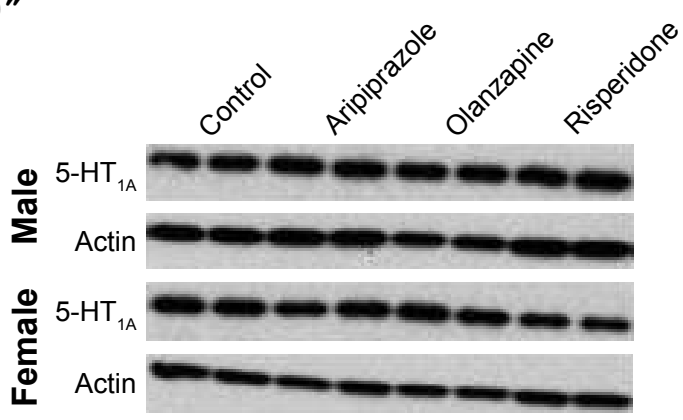

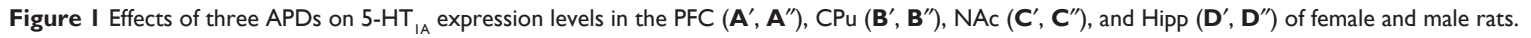

Notes: Sprague Dawley rats were treated chronically with aripiprazole (1.0 mg/kg, tid), olanzapine ( $1.0 \mathrm{mg} / \mathrm{kg}$, tid), risperidone ( $0.3 \mathrm{mg} / \mathrm{kg}$, tid), or control (vehicle). The number of samples per gender per group is 6 . Data were expressed as mean \pm SEM. $* P<0.05$ vs control. The representative bands of Western Blot are shown.

Abbreviations: APDs, antipsychotic drugs; CPu, caudate putamen; Hipp, hippocampus; 5-HT, serotonin; NAc, nucleus accumbens; PFC, prefrontal cortex; SEM, standard error of the mean; tid, three times daily. 


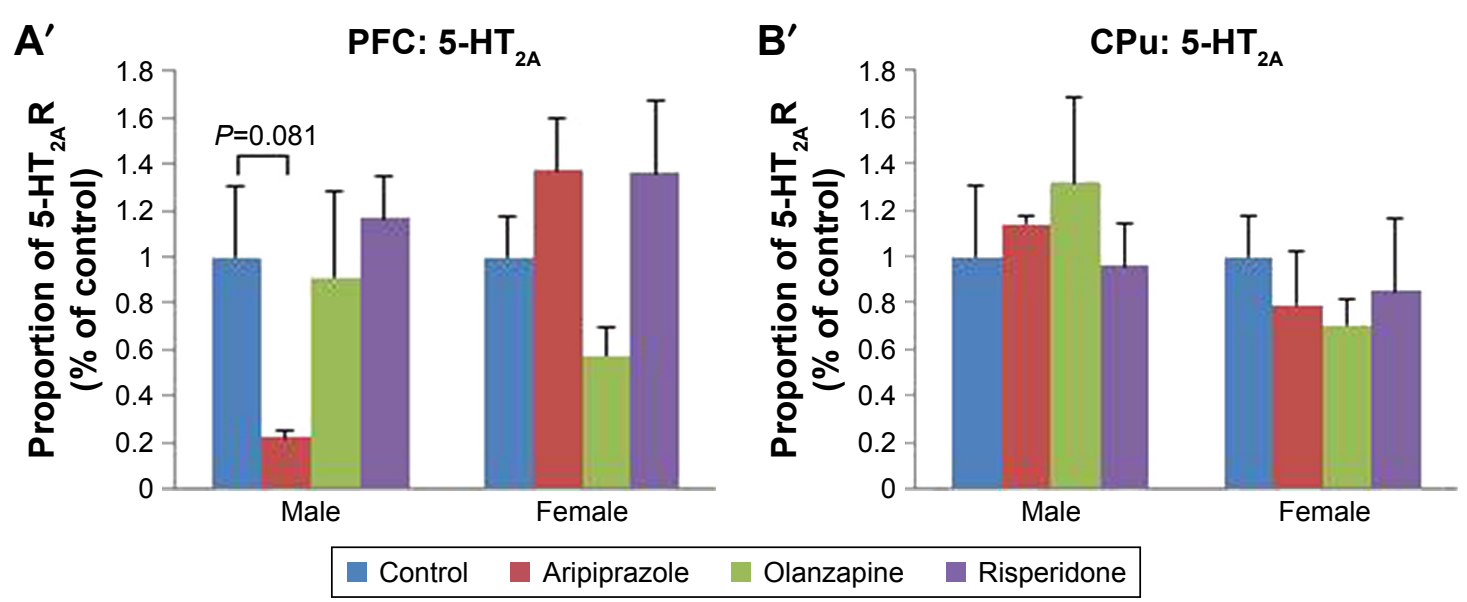

$\mathbf{A}^{\prime \prime}$

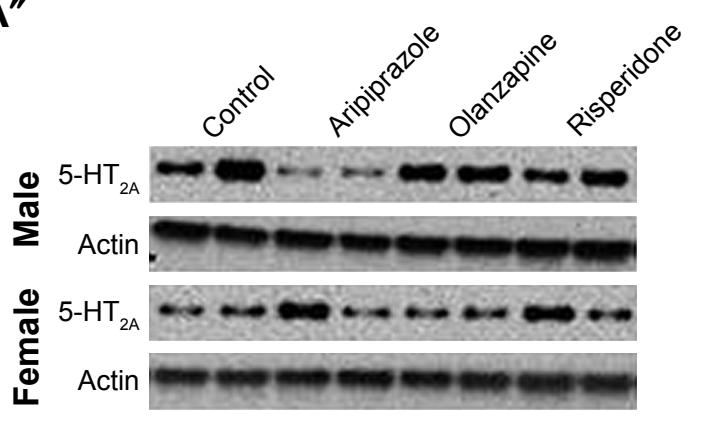

$\mathbf{C}^{\prime}$

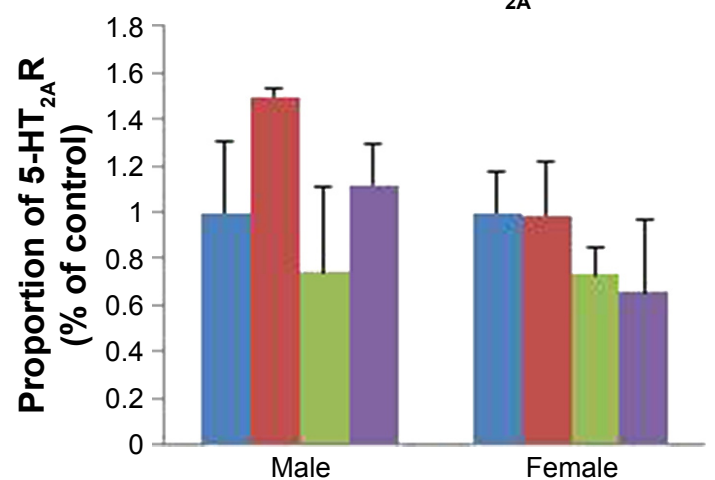

$\mathrm{B}^{\prime \prime}$

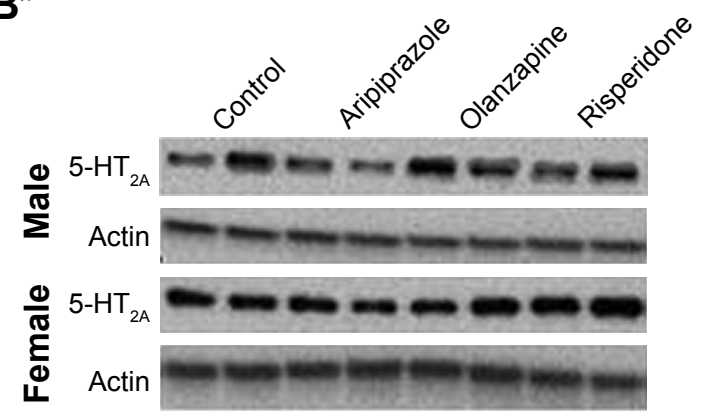

$D^{\prime}$

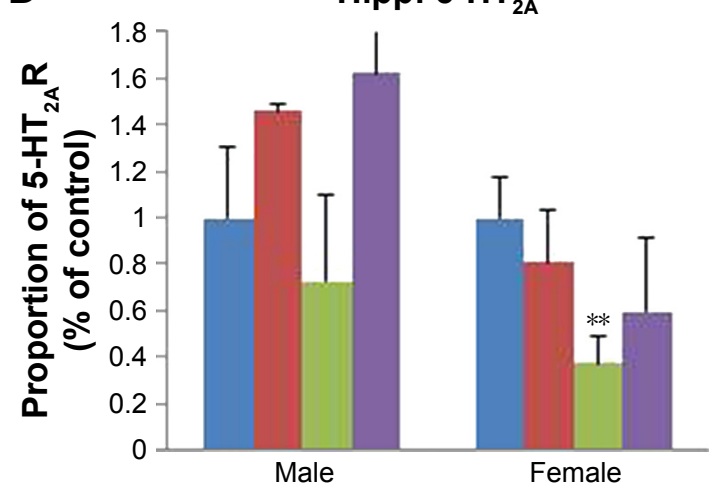

Control Aripiprazole Olanzapine $\quad$ Risperidone

$C^{\prime \prime}$

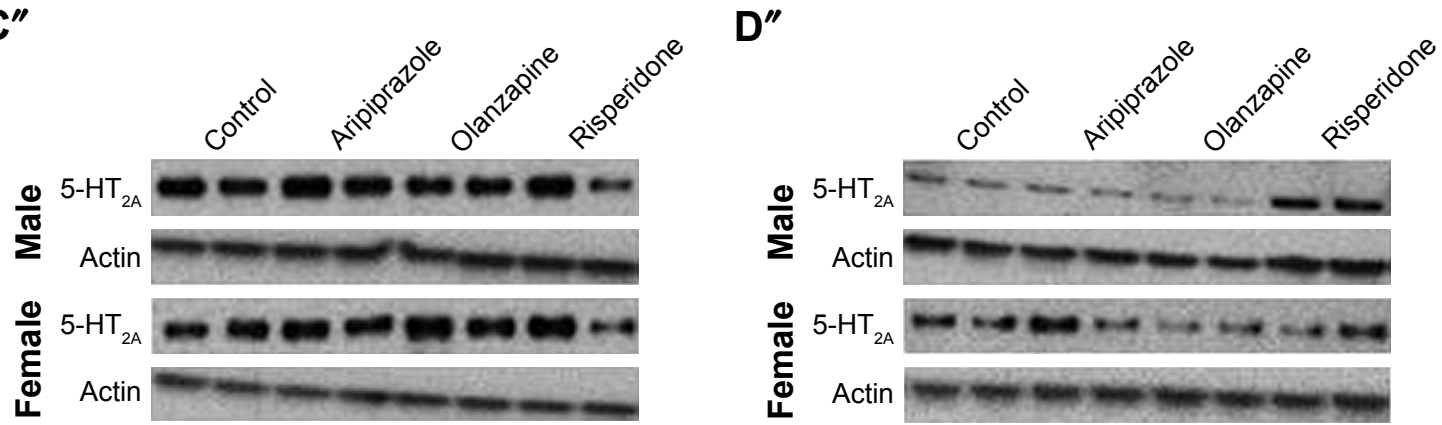

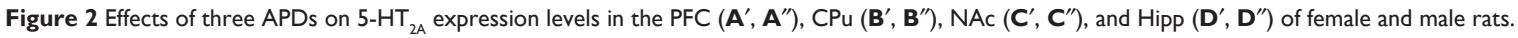

Notes: Sprague-Dawley rats were treated chronically with aripiprazole $(1.0 \mathrm{mg} / \mathrm{kg}$, tid), olanzapine ( $1.0 \mathrm{mg} / \mathrm{kg}$, tid), risperidone $(0.3 \mathrm{mg} / \mathrm{kg}$, tid), or control (vehicle). The number of samples per gender per group is 6. Data expressed as mean \pm SEM. $* * P<0.01$ vs control. The representative bands of Western Blot are shown.

Abbreviations: APDs, antipsychotic drugs; CPu, caudate putamen; Hipp, hippocampus; NAc, nucleus accumbens; 5-HT, serotonin; PFC, prefrontal cortex; SEM, standard error of the mean; tid, three times daily. 
A

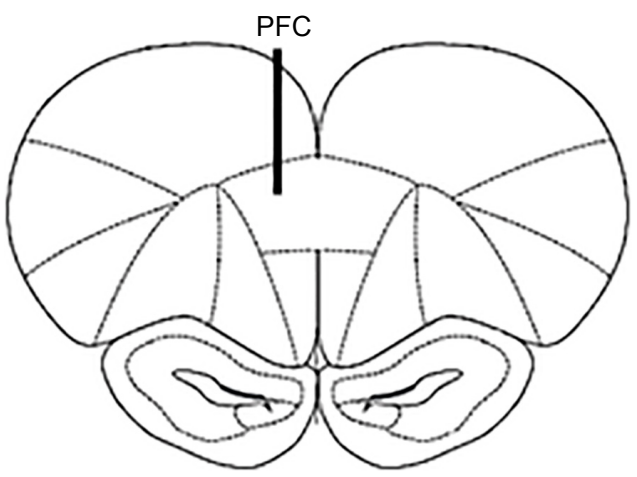

B

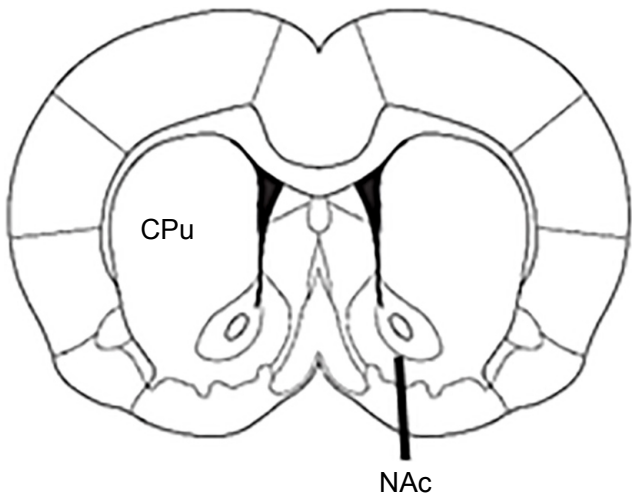

C

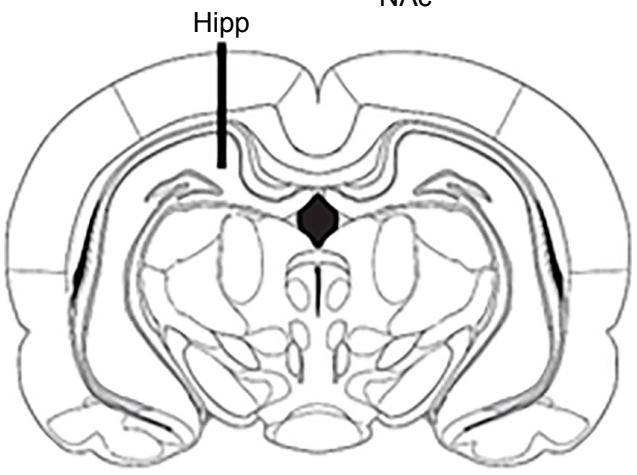

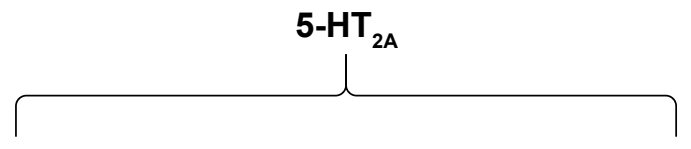
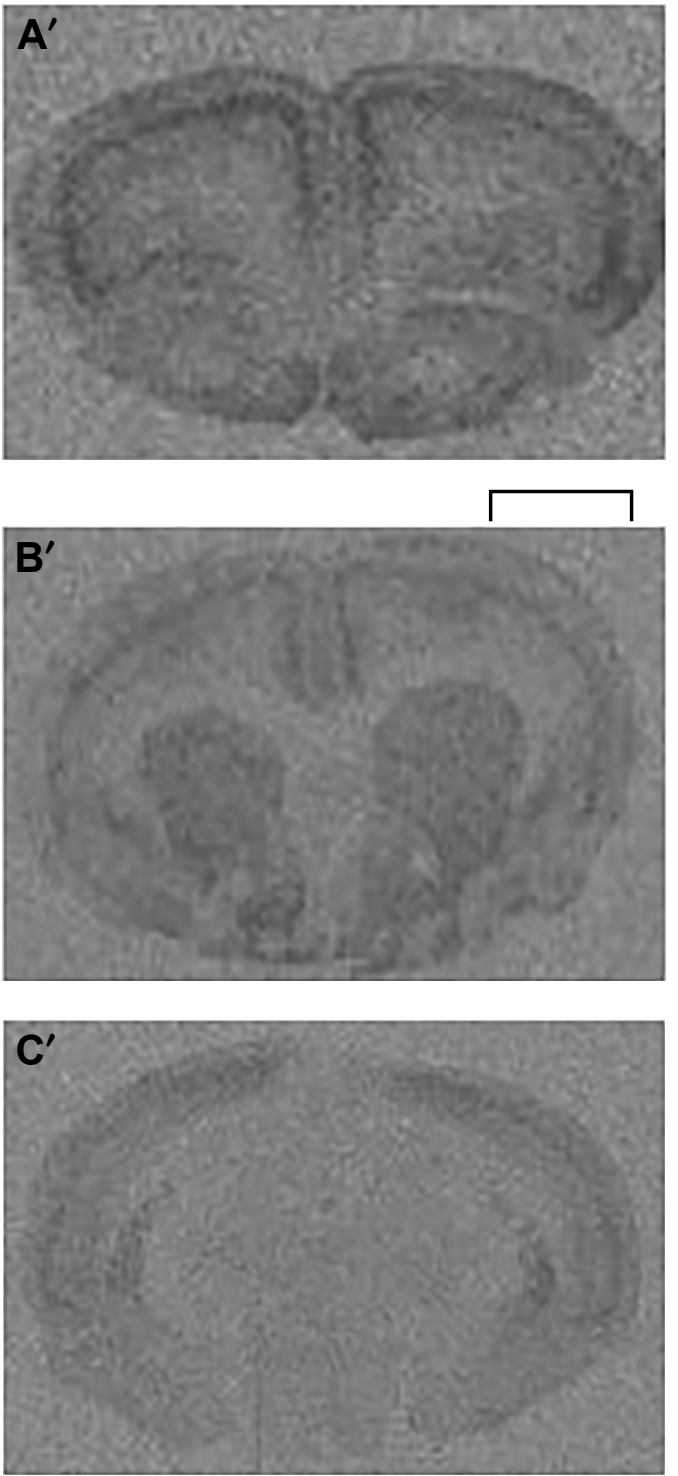

Figure 3 Examples of $5-\mathrm{HT}_{2 \mathrm{~A}}$ receptor binding in the adult rat brain following childhood/adolescent APD treatment.

Notes: The schematic diagram is adapted from Paxinos G, Watson C. The Rat Brain in Stereotaxic Coordinates. 6th edition. London: Elsevier; 2007. (C Academic Press 2007.68 Showing the level of Bregma for each investigated region (A: PFC, $4.68 \mathrm{~mm}$; B: CPu and NAc, $1.08 \mathrm{~mm}$; C: Hipp, $-2.76 \mathrm{~mm}$ ). (A'-C') Examples of autoradiograms to demonstrate $\left[{ }^{3} \mathrm{H}\right]$ Ketanserin binding to $5-\mathrm{HT}_{2 \mathrm{~A}}$ receptors. The scale bar applies to all autoradiograms and is $2.0 \mathrm{~mm}$ for $\mathrm{A}^{\prime}, 2.8 \mathrm{~mm}$ for $\mathrm{B}^{\prime}$, and $3.2 \mathrm{~mm}$ for $\mathrm{C}^{\prime}$.

Abbreviations: APD, antipsychotic drug; CPu, caudate putamen; Hipp, hippocampus; 5-HT, serotonin; NAc, nucleus accumbens; PFC, prefrontal cortex.

$P<0.001)$ of rats. Additionally, a significant effect of gender was found in the hippocampus $\left(F_{1,45}=16.265, P<0.001\right)$, while a significant interaction between the factors was also found in the hippocampus $\left(F_{3,45}=7.511, P<0.001\right)$. Post hoc analysis uncovered that early treatment with both aripiprazole $(-50.2 \%, P<0.05)$ and olanzapine $(-42.5 \%, P=0.078)$ significantly decreased $5-\mathrm{HT}_{2 \mathrm{C}}$ expression in the PFC in comparison to the control. Following analysis of the male cohort via one-way ANOVA, a significant effect of early
APD treatment was discovered in the PFC $\left(F_{3,20}=8.004\right.$, $P<0.01)$ and hippocampus $\left(F_{3,22}=15.474, P<0.001\right)$, while a trend to significant effect was found in the $\mathrm{CPu}$ $\left(F_{3,22}=2.946, P=0.059\right)$. Post hoc analysis found decreases in 5- $\mathrm{HT}_{2 \mathrm{C}}$ receptor expression in the PFC following early APD treatment with aripiprazole $(-45.1 \%, P<0.05)$ and olanzapine $(-50.1 \%, P<0.01)$ (Figures $4 \mathrm{~A}^{\prime}$ and $\mathrm{A}^{\prime \prime}$ and $\underline{\mathrm{S} 3}$ ). Additionally, increases in 5- $\mathrm{HT}_{2 \mathrm{C}}$ receptor expression were uncovered in the hippocampus following early treatment 
$\mathbf{A}^{\prime}$

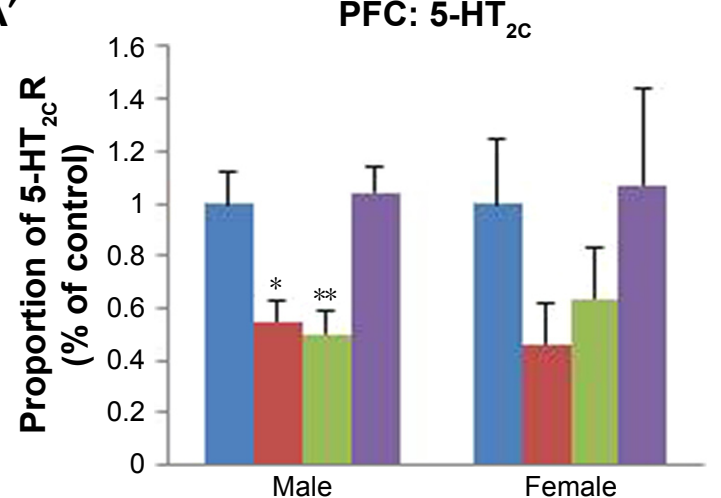

$\mathbf{B}^{\prime}$

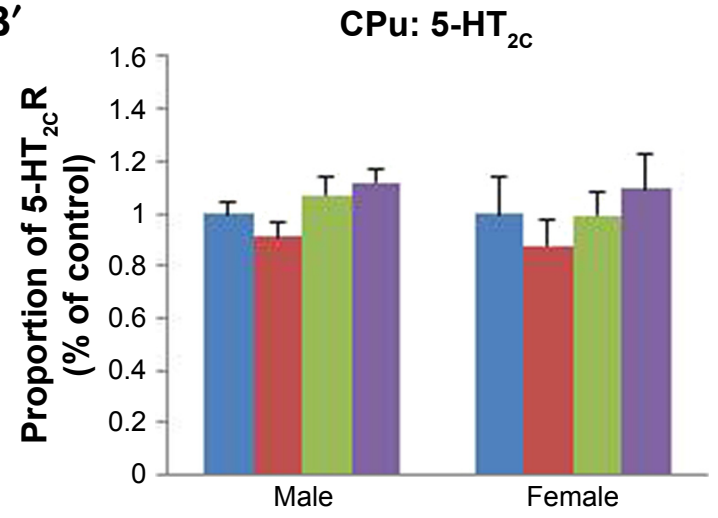

$\square$ Control $\square$ Aripiprazole Olanzapine $\square$ Risperidone

$A^{\prime \prime}$

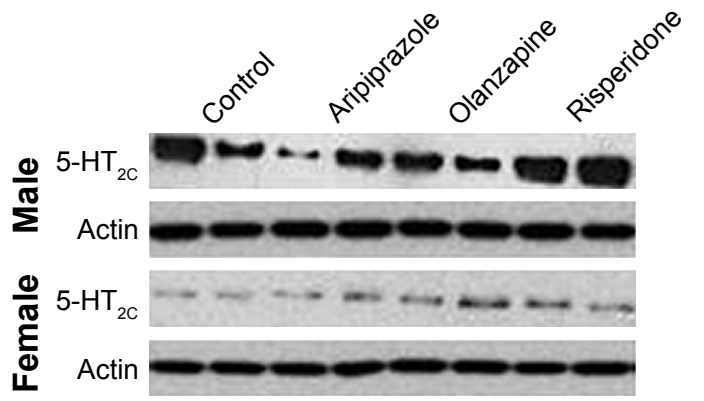

$\mathbf{C}^{\prime}$

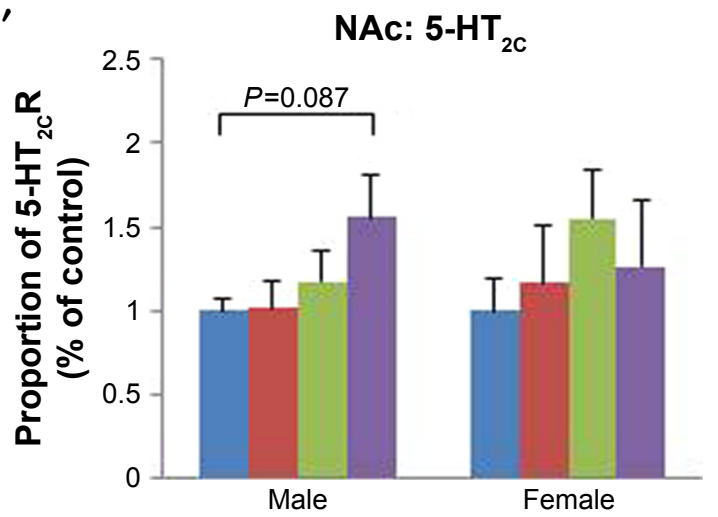

$B^{\prime \prime}$

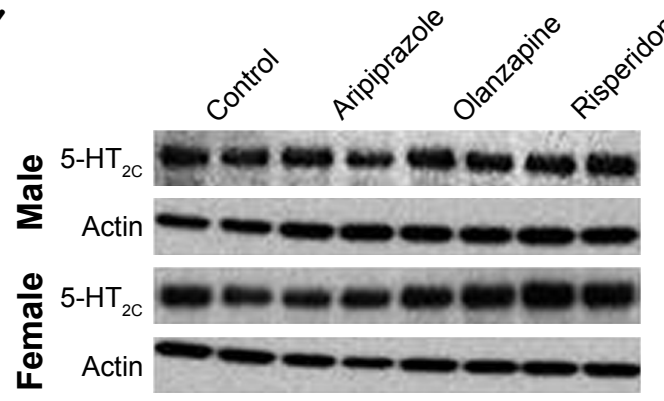

$\mathbf{D}^{\prime}$

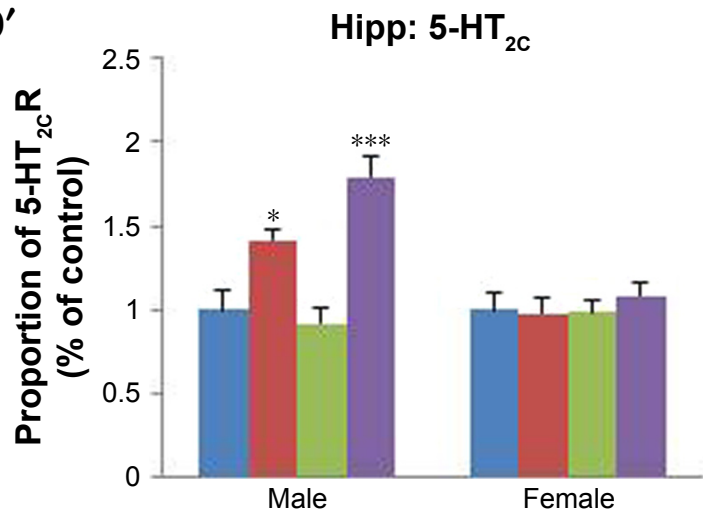

- Control aripiprazole $\quad$ Olanzapine $\quad$ Risperidone

$\mathbf{C}^{\prime \prime}$

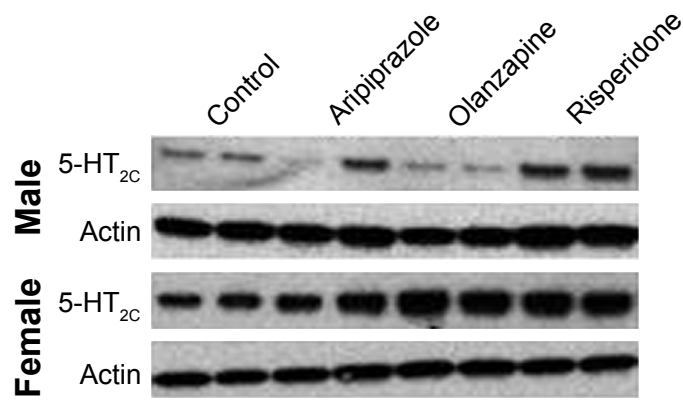

$D^{\prime \prime}$

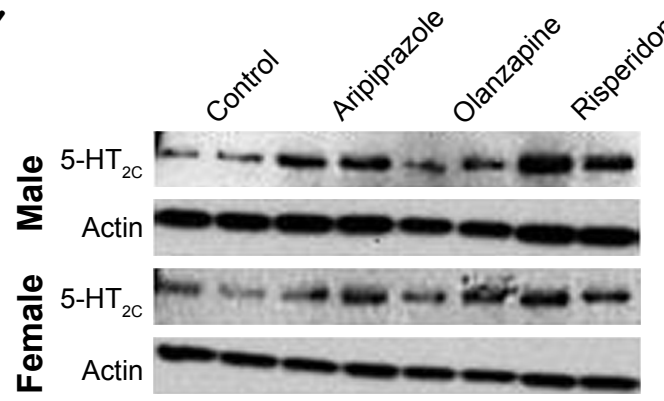

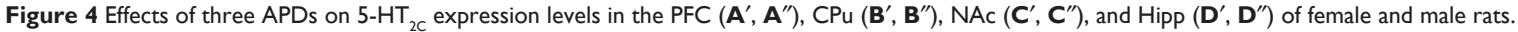

Notes: Sprague Dawley rats were treated chronically with aripiprazole $(1.0 \mathrm{mg} / \mathrm{kg}$, tid), olanzapine $(1.0 \mathrm{mg} / \mathrm{kg}$, tid), risperidone $(0.3 \mathrm{mg} / \mathrm{kg}$, tid), or control (vehicle). The number of samples per gender per group is 6 . Data expressed as mean $\pm S E M$. $* P<0.05, * * P<0.01$, $* * * P<0.00$ I vs control. The representative bands of Western Blot are shown.

Abbreviations: APDs, antipsychotic drugs; CPu, caudate putamen; Hipp, hippocampus; 5-HT, serotonin; NAc, nucleus accumbens; PFC, prefrontal cortex; SEM, standard error of the mean; tid, three times daily. 
with both aripiprazole $(+41.5 \%, P<0.05)$ and risperidone $(+79.6 \%, P<0.001)$ (Figures $4 \mathrm{D}^{\prime}$ and $\mathrm{D}^{\prime \prime}$ and $\underline{\mathrm{S} 3}$ ), while no alterations were uncovered in either the $\mathrm{CPu}$ (Figures $4 \mathrm{~B}^{\prime}$ and $\mathrm{B}^{\prime \prime}$ and $\underline{\mathrm{S} 3}$ ) or the NAc (Figures $4 \mathrm{C}^{\prime}$ and $\mathrm{C}^{\prime \prime}$ and $\underline{\mathrm{S}}$ ). No significant alterations to $5-\mathrm{HT}_{2 \mathrm{C}}$ receptor expression, however, were found in the female cohort.

\section{Discussion}

The present study has, for the first time, provided insight into the long-term effects of early (juvenile) treatment with the APDs aripiprazole, olanzapine, and risperidone on the density of 5-HT receptors in the adult brain. Our investigation has revealed that juvenile APD treatment during the critical neurodevelopmental time period resulted in significant long-term alterations to $5-\mathrm{HT}_{2 \mathrm{~A}}$ and $5-\mathrm{HT}_{2 \mathrm{C}}$ receptors, predominantly in hippocampal and cortical brain regions. Furthermore, we have uncovered more widespread alterations to the density of male 5-HT receptors in comparison to female 5-HT receptors, with changes in 5- $\mathrm{HT}_{2 \mathrm{~A}}$ and $5-\mathrm{HT}_{2 \mathrm{C}}$ receptors uncovered across multiple drug treatment groups.

While previous investigations into the long-term effects of juvenile APD use on 5- $\mathrm{HT}_{1 \mathrm{~A}}, 5-\mathrm{HT}_{2 \mathrm{~A}}$, and 5- $\mathrm{HT}_{2 \mathrm{C}}$ receptors have, to our knowledge, not been completed, numerous studies have examined the immediate effects of aripiprazole, olanzapine, or risperidone treatment on the density of 5-HT receptors in young ${ }^{45,46,69}$ and adult ${ }^{65,67,70,71}$ rodents, over both short- and long-term treatment periods. Such investigations have uncovered a trend for APD treatment to result in immediate decreases to both $5-\mathrm{HT}_{2 \mathrm{~A}}$ and $5-\mathrm{HT}_{2 \mathrm{C}}$ receptor subtypes following a cessation of treatment. We believe that our investigation is the first to identify that if treated in a juvenile animal, this alteration to 5-HT receptor density is still prominent in adulthood.

Long-term alterations to $5-\mathrm{HT}_{2 \mathrm{~A}}$ receptors after early $\mathrm{APD}$ exposure were uncovered in hippocampal and cortical brain regions in the current study. In the male cohort, significant decreases to the density of $5-\mathrm{HT}_{2 \mathrm{~A}}$ receptors were found in the hippocampus of adult brains following juvenile treatment with the APDs aripiprazole, olanzapine, and risperidone. Furthermore, similar decreases were also found in the PFC of those that underwent early treatment with aripiprazole and risperidone in comparison to the control. Decreases in $5-\mathrm{HT}_{2 \mathrm{~A}}$ receptor densities were also found in the hippocampus of females following treatment with the APDs olanzapine and risperidone.

Although previous investigations into the immediate effects of short- and long-term treatments with olanzapine have also found region-specific alterations to the density levels of 5- $\mathrm{HT}_{2 \mathrm{~A}}$ receptors of both young ${ }^{45,69}$ and adult ${ }^{67,70,71}$ rats, results from the current study extended that of previous findings. Specifically, while decreases in 5- $\mathrm{HT}_{2 \mathrm{~A}}$ levels have been observed in the hippocampus of the present study, previous investigations over multiple time periods, and across both genders, have found no changes to hippocampal $5-\mathrm{HT}_{2 \mathrm{~A}}$ receptor levels in the adult brain following olanzapine treatment. ${ }^{70,71}$ Furthermore, while no changes in 5- $\mathrm{HT}_{2 \mathrm{~A}}$ levels were uncovered in the PFC of our investigation, olanzapine has been found to immediately decrease PFC 5- $\mathrm{HT}_{2 \mathrm{~A}}$ receptor levels in young rats following short-term treatment periods ${ }^{45,69}$ and adult rats following both short-term ${ }^{70,71}$ and long-term treatment periods. ${ }^{67}$ While studies on the short- and long-term effects of risperidone treatment in both young and adult rats have also uncovered similar significant decreases in 5- $\mathrm{HT}_{2 \mathrm{~A}}$ receptor levels in the $\mathrm{PFC},{ }^{45,46,70}$ no changes in 5- $\mathrm{HT}_{2 \mathrm{~A}}$ levels in brain regions including the $\mathrm{CPu}, \mathrm{NAc}$, and hippocampus have been previously uncovered. ${ }^{45,69,70} \mathrm{In}$ addition, although significant decreases in 5- $\mathrm{HT}_{2 \mathrm{~A}}$ receptors were observed in both the hippocampus and PFC of animals treated with aripiprazole in the present study, limited investigations have previously been completed investigating the potential for aripiprazole's antagonistic actions on $5-\mathrm{HT}_{2 \mathrm{~A}}$ receptors to cause short- or long-term changes. While one investigation into the immediate effects of short-term treatment with aripiprazole has uncovered decreased levels of $5-\mathrm{HT}_{2 \mathrm{~A}}$ receptors in the PFC of young male rats, ${ }^{45}$ further investigations into the immediate and long-term effects of short- and long-term treatments will shed further light and allow further comparisons to be drawn to the current investigation findings.

In addition to the $5-\mathrm{HT}_{2 \mathrm{~A}}$ receptor changes, alterations to the 5- $\mathrm{HT}_{2 \mathrm{C}}$ receptor were found in the PFC and hippocampus of males only in the present study. Contrasting results were revealed between the aforementioned regions, with decreases in 5- $\mathrm{HT}_{2 \mathrm{C}}$ receptor levels uncovered in the PFC of adult male rodents following juvenile treatment with aripiprazole and olanzapine, while increases were found in the hippocampus of aripiprazole- and risperidone-treated groups in comparison to control.

Previous investigations into the immediate effects of APD treatment on $5-\mathrm{HT}_{2 \mathrm{C}}$ receptor density levels have found differing results to that observed by the current study, where long-lasting effects were revealed. First, contrary to our study, alterations to $5-\mathrm{HT}_{2 \mathrm{C}}$ receptors have been found across both male and female rodents in studies of varying treatment durations, utilizing both young and adult models, and through multiple brain regions. In addition, while olanzapine treatment has been found to decrease $5-\mathrm{HT}_{2 \mathrm{C}}$ levels in 
the PFC of studies, investigations into the immediate effects of short- and long-term APD treatment on 5- $\mathrm{HT}_{2 \mathrm{C}}$ receptors in the hippocampus of young and adult rodents have found treatment with olanzapine resulted in either a decrease or no change in the density of receptors..$^{45,67,70,71}$ In particular, while short-term olanzapine treatment of both young male and female rodents resulted in immediate decreases across cortical and striatal brain regions, ${ }^{45}$ variations in results have been found in the immediate effects of adult olanzapine treatment models over both short-term ${ }^{70,71}$ and long-term periods, ${ }^{67}$ with either decreases or no change in receptor densities found in investigated brain regions including PFC, $\mathrm{CPu}, \mathrm{NAc}$, and hippocampus. Investigations into the effects of aripiprazole and risperidone on 5-HT2C receptor have been concentrated on the immediate effects of short-term treatment periods, with no alterations to any brain regions found following short-term aripiprazole treatment across both male and female young animals ${ }^{45}$ or short-term risperidone treatment in adult male rodents. ${ }^{70}$

Minimal changes in adult 5- $\mathrm{HT}_{1 \mathrm{~A}}$ receptors were uncovered following juvenile APD treatment in the present study. Decreases in 5- $\mathrm{HT}_{1 \mathrm{~A}}$ receptor density levels in the adult brain were uncovered in the NAc following juvenile risperidone APD treatment in the male cohort, and in the NAc of female rodents treated with aripiprazole in comparison to the control. Previous investigations once again centered upon uncovering the immediate effect of treatment on $5-\mathrm{HT}_{1 \mathrm{~A}}$ receptor density levels, with the majority of studies revealing no changes in receptor levels following APD treatment with aripiprazole, olanzapine, or risperidone in investigated regions. Some short-term studies did however reveal that acute and short-term treatment in both young and adult rats increased $5-\mathrm{HT}_{1 \mathrm{~A}}$ receptor density levels. ${ }^{46,70}$ Specifically, while increases in 5- $\mathrm{HT}_{1 \mathrm{~A}}$ receptor density levels have been found previously across both the PFC and hippocampus of both young and adult male rodents following short-term treatment with risperidone and olanzapine, ${ }^{46,70}$ acute treatment of female rats with aripiprazole has also uncovered increases in $5-\mathrm{HT}_{1 \mathrm{~A}}$ levels in the hippocampus. No alterations, however, were found following acute and long-term olanzapine or haloperidol treatments and across cortical and hypothalamic brain regions. ${ }^{65}$

The minimal observed alterations to the $5-\mathrm{HT}_{1 \mathrm{~A}}$ receptor in comparison to $5-\mathrm{HT}_{2 \mathrm{~A}}$ and $5-\mathrm{HT}_{2 \mathrm{C}}$ may be due to a number of factors. First, of the three APDs investigated in the current study, only aripiprazole has been found to have a significant affinity for the $5-\mathrm{HT}_{1 \mathrm{~A}}$ receptor, ${ }^{65,72}$ while the similar antagonistic pharmacological profile of olanzapine and risperidone on $5-\mathrm{HT}_{2 \mathrm{~A}}$ and $5-\mathrm{HT}_{2 \mathrm{C}}$ receptors may be resulting in the comparable decreases in adult brain receptor density levels between the two receptor subtypes. ${ }^{22}$ The $5-\mathrm{HT}_{1 \mathrm{~A}}$ is known to be located both pre- and postsynaptically and have autoreceptor functions. ${ }^{38,73,74}$ Investigations have found that the 5-HT receptor located presynaptically in the dorsal raphe nucleus, performing regulatory functions for the 5-HT NT, and also located postsynaptically in limbic structures including the hippocampus, performing traditional postsynaptic receptor functions. ${ }^{38,73,74}$

The repeated antagonism of the $5-\mathrm{HT}_{2 \mathrm{~A}}$ and $5-\mathrm{HT}_{2 \mathrm{C}}$ receptors, along with the presynaptic $5-\mathrm{HT}_{1 \mathrm{~A}}$ receptor, has the potential to result in a downregulation in number and sensitivity and subsequently a long-term deficiency in 5-HT NT signaling. ${ }^{38,75,76}$ With the $5-\mathrm{HT}_{2 \mathrm{~A}}$ receptor in particular well known to play critical roles in both APD treatment efficacy ${ }^{19-22}$ and the regulation and functioning of the 5-HT NT system, ${ }^{36-38,77,78}$ and with previous investigations demonstrating a correlative functions of the 5-HT NT in the pathophysiology of multiple mental illnesses, ${ }^{16,22,29,38,79,80}$ any disturbances to the regulation of the 5-HT NT system, such as through early APD treatment targeting 5-HT receptors, have the potential to alter 5-HT transmission and, thus, elicit related changes to multiple facets of mental illness over long term. Furthermore, the subsequent deficiency in projections of the 5-HT NT has been found to result in the disinhibition and therefore enhancement of the DA signal ${ }^{36-38}$ and correlated to changes in behaviors, as demonstrated in our previous investigations. ${ }^{35,39}$ Changes in behaviors including enhanced locomotor activity ${ }^{36,37}$ and anxiolytic and decreased depressive-like behaviors ${ }^{8,36,75,81-84}$ have previously been uncovered and correlated to the repeated antagonism of the $5-\mathrm{HT}_{2}$ receptor, potentially the negatively correlated alterations to the DA signal.

APDs such as aripiprazole have also been found to elicit partial agonist effects on presynaptic $5-\mathrm{HT}_{1 \mathrm{~A}}$ receptors in the dorsal raphe nuclei of previously investigated brains, ${ }^{76,85}$ Investigations into the effects of APD treatment on 5-HT receptors in the dorsal raphe nuclei, however, will need to be the focus of future studies, as the focus of the current investigations only shifted to the 5-HT NT system following previous results, and thus, no relevant tissue is available for analysis.

With previous investigations into the effects of APD treatment on 5-HT receptors centered upon revealing any immediate changes in receptor density levels, and the current study looking into long-lasting effects, the contrasting results between the current and previous investigations may be the 
product of a myriad of influencing factors. Factors including the treatment duration of the study, differences in age of the animals treated, and duration of time between the cessation of APD treatment and detection of 5-HT receptors have previously been highlighted as having the potential to influence the observed results, with the current study specifically investigating the long-term effects of juvenile APD treatment on 5-HT receptors in the adult brain. There is the potential that the alterations to measured variables uncovered in the present study may have occurred following the cessation of APD treatment and during the drug withdrawal period. During such time, the antagonistic action of APDs on 5-HT receptors in an adult brain may result in a short-term over-compensatory increase in receptor numbers (as observed in previous investigations ${ }^{65}$ ), followed by a regulation of density over long term. Drug treatment during the critical neurodevelopmental time period may subsequently result in a long-term decrease in morphology and/or density over the large time duration, in a process previously labeled as neuronal imprinting. ${ }^{25}$ Previous studies have demonstrated similar age-dependent effects of drug treatment, with psychotropic drugs such as fluoxetine (a selective serotonin re-uptake inhibitor [SSRI]) previously proven to elicit different effects on a juvenile compared to an adult, mature brain. ${ }^{25,34,86,87}$

Chronologically, and as outlined briefly earlier, 5-HT is also known to play a significant role first as a trophic factor in overall brain development and then undergo significant neurodevelopmental phases itself as the NT system develops from birth through to adulthood. ${ }^{8,31}$ Specifically, the 5-HT ligand, along with the 5- $\mathrm{HT}_{1 \mathrm{~A}}$ receptor, has been found to play key roles in overall axonal growth and synapse formation throughout the brain. ${ }^{88}$ Alterations to baseline levels of 5-HT during these early critical phases of neurodevelopment, through either intrinsic or extrinsic factors (eg, early APD treatment), have been found to alter the developmental trajectory of the adult brain and subsequently impact the adult brain functioning. ${ }^{8,26,30,32,88}$ Therefore, there is the potential that the juvenile APD treatment utilized in the present study, with a high affinity and potent actions on the 5-HT NT system, has impacted not only the observed long-lasting changes in 5-HT receptors but also widespread long-lasting alterations to overall axonal growth, neurite, and dendrite formations.

Additionally, and as indicated previously, gender-specific alterations to adult 5-HT receptor density levels were also observed following juvenile APD treatment in the present study. In particular, more widespread alterations to the $5-\mathrm{HT}_{2 \mathrm{~A}}$ and $5-\mathrm{HT}_{2 \mathrm{C}}$ receptors were uncovered in the PFC and hippocampus of males, while minimal alterations were observed in the female cohort across all investigated 5-HT receptor subtypes and across all four brain regions and APD treatment groups. Potential influencing factors on the observed gender differences in results have been outlined extensively in previous publications. ${ }^{35,39}$ Specifically, the well-known differences in the development and expression of 5-HT receptors between genders ${ }^{89}$ and with the influence of the sex hormones testosterone and estrogen ${ }^{26,82,89-91}$ have the potential to play a role in the observed gender differences. Previously demonstrated gender variations to 5-HTmediated functions have an obvious potential to influence the observed results, ${ }^{89,92}$ with the sex hormones testosterone and estrogen found to play a critical role. ${ }^{89,91,93-96}$ Changes in the levels of the sex hormone estrogen have been found to influence the levels of 5-HT ligand in brain regions including the cortex and raphe nucleus ${ }^{94-96}$ and, furthermore, alter the density levels of 5- $\mathrm{HT}_{1 \mathrm{~A}}$ and 5- $\mathrm{HT}_{2}$ receptors in brain regions including the cortex, raphe nucleus, and hippocampus. ${ }^{89}$ Additionally, estrogen has previously been found to play a neuro-protective effect on 5-HT NT system, with studies uncovering its ability to inhibit behavioral changes in information processing mediated by both the $5-\mathrm{HT}_{1 \mathrm{~A}}$ and $\mathrm{DA} \mathrm{D}_{2}$ receptors, an attribute that found deficient in people suffering from mental illness. ${ }^{90}$

\section{Conclusion}

The current study has uncovered the potential for treatment with the APDs aripiprazole, olanzapine, and risperidone during the critical neurodevelopmental period to cause longlasting alterations to the density of 5-HT receptors in the adult brain. In particular, significant alterations to $5-\mathrm{HT}_{2 \mathrm{~A}}$ and $5-\mathrm{HT}_{2 \mathrm{C}}$ receptors in cortical and hippocampal brain regions were observed in the male cohort across aripiprazole, olanzapine, and risperidone APD treatment groups in comparison to controls. These observed changes are in addition to the alterations to various behavioral attributes (including anxiety and depressive-like behaviors) and the dopamine NT system (including receptors, transporters, and synthesis markers) previously reported with the same treatment model in our laboratory. ${ }^{35,39}$ Although the observed alterations to the 5-HT NT system in the investigated regions provide some evidence of the potential for early APD treatment to elicit long-term alterations to a NT system functioning, further investigations have the potential to uncover both the scope of changes elicited on the 5-HT NT system and potential alterations to other NT groups. Other NT systems including the adrenergic and muscarinic NT systems are also known to be a part of the pharmacological mechanisms of action of 
APDs and interplay with other NT systems, ${ }^{37,97-99}$ and thus, antagonist actions during the critical neurodevelopmental time period have the potential to elicit long-lasting changes that may be exhibited clinically. Furthermore, investigations into the effects of juvenile APD in a disease animal model would also provide invaluable insight into the potential longlasting effects of treatment during such a critical neurodevelopmental time period. The alterations observed in the present study provide some of the first evidence of the potential of juvenile APD treatment with aripiprazole, olanzapine, and risperidone to elicit long-term alterations to the 5-HT NT system in the adult brain. With all three APDs approved for use in adolescents with various medical conditions and also known to be prescribed off-label, the potential long-term effects of early use should be highlighted before they are prescribed clinically, especially in the male cohort where the vast majority of alterations have been found.

\section{Acknowledgments}

The current study was supported by an Australian National Health and Medical Research Council project grant (APP1104184) awarded to CD. MDS is supported by Australian Rotary Health in the form of an Ian Scott PhD Scholarship. This research has also been conducted with the support of the Australian Government Research Training Program Scholarship.

\section{Author contributions}

All authors contributed toward data analysis, drafting and critically revising the paper, gave final approval of the version to be published, and agree to be accountable for all aspects of the work.

\section{Disclosure}

The authors report no conflicts of interest in this work.

\section{References}

1. Alexander GC, Gallagher SA, Mascola A, Moloney RM, Stafford RS. Increasing off-label use of antipsychotic Medications in the United States. Pharmacoepidemiol Drug Saf. 2011;20(2):177-184.

2. Seida JC, Schouten JR, Boylan K, et al. Antipsychotics for children and young adults: a comparative effectiveness review. Pediatrics. 2012; 129(3): e771-e784.

3. Olfson M, Blanco C, Liu S, Wang S, Correll CU. National trends in the office-based treatment of children, adolescents, and adults with antipsychotics. Arch Gen Psychiatry. 2012;69(12):1247-1256.

4. Rani F, Murray ML, Byrne PJ, Wong ICK. Epidemiologic features of antipsychotic prescribing to children and adolescents in primary care in the United Kingdom. Pediatrics. 2008;121(5):1002-1009.

5. Olfson M, Crystal S, Huang C, Gerhard T. Trends in antipsychotic drug use by very young, privately insured children. J Am Acad Child Adolesc Psychiatry. 2010;49(1):13-23.
6. Varley CK, McClellan J. Implications of marked weight gain associated with atypical antipsychotic medications in children and adolescents. JAMA. 2009;302(16):1811-1812.

7. Hoekstra PJ. Risperidone for non-psychotic disorders in paediatric patients: which child is to benefit? Dev Med Child Neurol. 2014; 56(10):919-920.

8. Andersen SL, Navalta CP. Altering the course of neurodevelopment: a framework for understanding the enduring effects of psychotropic drugs. Int J Dev Neurosci. 2004;22(5-6):423-440.

9. Memarzia J, Tracy D, Giaroli G. The use of antipsychotics in preschoolers: a veto or a sensible last option? J Psychopharmacol. 2014;28(4): 303-319.

10. Moe AAK, Scott JG, Burne THJ, Eyles DW. Neural changes induced by antipsychotic administration in adolescence: a review of studies in laboratory rodents. J Psychopharmacol. 2016;30(8):771-794.

11. Madden C, Black B, Willsie D. Treating our youngest patients: psychotropic medications in early childhood. Mo Med. 2014;111(3):207-211.

12. Schneider C, Taylor D, Zalsman G, Frangou S, Kyriakopoulos M. Antipsychotics use in children and adolescents: an on-going challenge in clinical practice. J Psychopharmacol. 2014;28(7):615-623.

13. Haw C, Stubbs J. Off-label use of antipsychotics: are we mad? Expert Opin Drug Saf. 2007;6(5):533-545.

14. Vitiello B, Correll C, van Zwieten-Boot B, Zuddas A, Parellada M, Arango C. Antipsychotics in children and adolescents: increasing use, evidence for efficacy and safety concerns. Eur Neuropsychopharmacol. 2009;19(9):629-635.

15. Sharma A, Shaw SR. Efficacy of risperidone in managing maladaptive behaviors for children with autistic spectrum disorder: a meta-analysis. J Pediatr Health Care. 2012;26(4):291-299.

16. Grace AA, Floresco SB, Goto Y, Lodge DJ. Regulation of firing of dopaminergic neurons and control of goal-directed behaviors. Trends Neurosci. 2007;30(5):220-227.

17. Kegeles LS, Abi-Dargham A, Frankle WG, et al. Increased synaptic dopamine function in associative regions of the striatum in schizophrenia. Arch Gen Psychiatry. 2010;67(3):231-239.

18. Purves-Tyson TD, Handelsman DJ, Double KL, Owens SJ, Bustamante S, Weickert CS. Testosterone regulation of sex steroid-related mRNAs and dopamine-related mRNAs in adolescent male rat substantia nigra. BMC Neurosci. 2012;13(1):95.

19. Milstein JA, Elnabawi A, Vinish M, et al. Olanzapine treatment of adolescent rats causes enduring specific memory impairments and alters cortical development and function. PLoS One. 2013;8(2):e57308.

20. Meltzer HY. Mechanism of action of atypical antipsychotic drugs. In: Davis KL, Charney D, Coyle JT, Nemeroff C, editors. Neuropsychopharmacology: The Fifth Generation of Progress. Nashville, TN: American College of Neuropsychopharmacology; 2002:819-831.

21. Nasrallah HA. Atypical antipsychotic-induced metabolic side effects: insights from receptor-binding profiles. Mol Psychiatry. 2008;13(1): $27-35$.

22. Amato D. Serotonin in antipsychotic drugs action. Behav Brain Res. 2015;277:125-135.

23. Levitt P, Harvey JA, Friedman E, Simansky K, Murphy EH. New evidence for neurotransmitter influences on brain development. Trends Neurosci. 1997;20(6):269-274.

24. Frost DO, Cadet JL. Effects of methamphetamine-induced neurotoxicity on the development of neural circuitry: a hypothesis. Brain Res Rev. 2000;34(3):103-118.

25. Klomp A, Tremoleda JL, Wylezinska M, et al. Lasting effects of chronic fluoxetine treatment on the late developing rat brain: age-dependent changes in the serotonergic neurotransmitter system assessed by pharmacological MRI. Neuroimage. 2012;59(1):218-226.

26. Andersen SL. Trajectories of brain development: point of vulnerability or window of opportunity? Neurosci Biobehav Rev. 2003;27(1-2): 3-18.

27. Marco EM, Adriani W, Ruocco LA, Canese R, Sadile AG, Laviola G. Neurobehavioral adaptations to methylphenidate: the issue of early adolescent exposure. Neurosci Biobehav Rev. 2011;35(8):1722-1739. 
28. Cousins L, Goodyer IM. Antidepressants and the adolescent brain. J Psychopharmacol. 2015;29(5):545-555.

29. Piontkewitz Y, Arad M, Weiner I. Tracing the development of psychosis and its prevention: what can be learned from animal models. Neuropharmacology. 2012;62(3):1273-1289.

30. Diefenbach TJ, Sloley BD, Goldberg JI. Neurite branch development of an identified serotonergic neuron from embryonic helisoma: evidence for autoregulation by serotonin. Dev Biol. 1995;167(1):282-293.

31. Dinopoulos A, Dori I, Parnavelas JG. The serotonin innervation of the basal forebrain shows a transient phase during development. Brain Res Dev Brain Res. 1997;99(1):38-52.

32. Whitaker-Azmitia PM. Serotonin and brain development: role in human developmental diseases. Brain Res Bull. 2001;56(5):479-485.

33. Song NN, Zhang Q, Huang Y, Chen L, Ding YQ, Zhang L. Enhanced dendritic morphogenesis of adult hippocampal newborn neurons in central 5-HT-deficient mice. Stem Cell Res. 2017;19:6-11.

34. Bottelier MA, Schouw MLJ, Klomp A, et al. The effects of Psychotropic Drugs On Developing Brain (ePOD) study: methods and design. $B M C$ Psychiatry. 2014;14(1):48.

35. De Santis M, Lian J, Huang XF, Deng C. Early antipsychotic treatment in juvenile rats elicits long-term alterations to the dopamine neurotransmitter system. Int J Mol Sci. 2016;17(11):1944.

36. Seo D, Patrick CJ, Kennealy PJ. Role of serotonin and dopamine system interactions in the neurobiology of impulsive aggression and its comorbidity with other clinical disorders. Aggress Violent Behav. 2008;13(5):383-395.

37. Kusljic S, Copolov DL, van den Buuse M. Differential role of serotonergic projections arising from the dorsal and median raphe nuclei in locomotor hyperactivity and prepulse inhibition. Neuropsychopharmacology. 2003;28(12):2138-2147.

38. Kapur S, Remington G. Serotonin-dopamine interaction and its relevance to schizophrenia. Am J Psychiatry. 1996;153(4):466-476.

39. De Santis M, Lian J, Huang XF, Deng C. Early antipsychotic treatment in childhood/adolescent period has long-term effects on depressive-like, anxiety-like and locomotor behaviours in adult rats. J Psychopharmacol. 2016;30(2):204-214.

40. Kumra S, Oberstar JV, Sikich L, et al. Efficacy and tolerability of second-generation antipsychotics in children and adolescents with schizophrenia. Schizophr Bull. 2008;34(1):60-71.

41. Stigler KA, McDougle CJ, Posey DJ, Potenza MN. Weight gain associated with atypical antipsychotic use in children and adolescents: prevalence, clinical relevance, and management. Pediatr Drugs. 2004;6(1):33-44.

42. Zuddas A, Zanni R, Usala T. Second generation antipsychotics (SGAs) for non-psychotic disorders in children and adolescents: a review of the randomized controlled studies. Eur Neuropsychopharmacol. 2011; 21(8):600-620.

43. Shu Q, Hu G, Li M. Adult response to olanzapine or clozapine treatment is altered by adolescent antipsychotic exposure: a preclinical test in the phencyclidine hyperlocomotion model. J Psychopharmacol. 2014;28(4):363-375.

44. Varela FA, Der-Ghazarian T, Lee RJ, Charntikov S, Crawford CA, McDougall SA. Repeated aripiprazole treatment causes dopamine D2 receptor up-regulation and dopamine supersensitivity in young rats. J Psychopharmacol. 2014;28(4):376-386.

45. Lian J, Pan B, Deng C. Early antipsychotic exposure affects serotonin and dopamine receptor binding density differently in selected brain loci of male and female juvenile rats. Pharmacol Rep. 2016;68(5):1028-1035.

46. Choi YK, Moran-Gates T, Gardner MP, Tarazi FI. Effects of repeated risperidone exposure on serotonin receptor subtypes in developing rats. Eur Neuropsychopharmacol. 2010;20(3):187-194.

47. Moran-Gates T, Gan L, Park YS, Zhang K, Baldessarini RJ, Tarazi FI. Repeated antipsychotic drug exposurein developing rats: dopamine receptor effects. Synapse. 2006;59(2):92-100.

48. Vinish M, Elnabawi A, Milstein JA, et al. Olanzapine treatment of adolescent rats alters adult reward behavior and nucleus accumbens function. Int J Neuropsychopharmacol. 2012;16(7):1599-1609.

49. Taylor D, Paton C, Kapur S. Maudsley Prescribing Guidelines. 10 ed. New York: Informa Healthcare; 2009.
50. Aravagiri M, Marder SR. Brain, plasma and tissue pharmacokinetics of risperidone and 9-hydroxyrisperidone after separate oral administration to rats. Psychopharmacology. 2002;159(4):424-431.

51. Reagan-Shaw S, Nihal M, Ahmad N. Dose translation from animal to human studies revisited. FASEB J. 2008;22(3):659-661.

52. US Department of Health and Human Services, Food and Drug Administration, Center for Drug Evaluation and Research (CDER); 2005. Guidance for Industry: Estimating the Maximum Safe Starting Dose in Initial Clinical Trials for Therapeutics in Adult Healthy Volunteers. Available from: https://www.fda.gov/downloads/drugs/guidances/ ucm078932.pdf. Accessed February 2, 2018.

53. Wadenberg MLG. Bifeprunox: a novel antipsychotic agent with partial agonist properties at dopamine D2 and serotonin 5-HT1A receptors. Future Neurol. 2007;2(2):153-165.

54. Kapur S, VanderSpek SC, Brownlee BA, Nobrega JN. Antipsychotic dosing in preclinical models is often unrepresentative of the clinical condition: a suggested solution based on in vivo occupancy. J Pharmacol Exp Ther. 2003;305(2):625-631.

55. Natesan S, Reckless GE, Nobrega JN, Fletcher PJ, Kapur S. Dissociation between in vivo occupancy and functional antagonism of dopamine D2 receptors: comparing aripiprazole to other antipsychotics in animal models. Neuropsychopharmacology. 2006;31(9):1854-1863.

56. Lian J, De Santis M, He M, Deng C. Risperidone-induced weight gain and reduced locomotor activity in juvenile female rats: the role of histaminergic and NPY pathways. Pharmacol Res. 2015;95-96:20-26.

57. He M, Zhang Q, Deng C, Wang H, Lian J, Huang XF. Hypothalamic histamine $\mathrm{H} 1$ receptor-AMPK signaling time-dependently mediates olanzapine-induced hyperphagia and weight gain in female rats. Psychoneuroendocrinology. 2014;42:153-164.

58. Zhang Q, Lian J, He M, Deng C, Wang H, Huang XF. Olanzapine reduced brown adipose tissue thermogenesis and locomotor activity in female rats. Prog Neuropsychopharmacol Biol Psychiatry. 2014;51: 172-180.

59. Zhang Q, He M, Deng C, Wang H, Lian J, Huang XF. Hypothalamic ghrelin signalling mediates olanzapine-induced hyperphagia and weight gain in female rats. Int $J$ Neuropsychopharmacol. 2014;17(5): 807-818.

60. Deng C, Pan B, Hu CH, Han M, Huang XF. Differential effects of short- and long-term antipsychotic treatment on the expression of neuregulin-1 and ErbB4 receptors in the rat brain. Psychiatry Res. 2015; 225(3):347-354.

61. Islam MR, Moriguchi S, Tagashira H, Fukunaga K. Rivastigmine restores 5-HT 1A receptor levels in the hippocampus of olfactory bulbectomized mice. Adv Alzheimer's Dis. 2014;3(3):128-136.

62. Pavone LM, Spina A, Rea S, et al. Serotonin transporter gene deficiency is associated with sudden death of newborn mice through activation of TGF-ß1 signalling. J Mol Cell Cardiol. 2009;47(5):691-697.

63. Sheikhkanloui-Milan H, Sheibani V, Afarinesh M, Esmaeili-Mahani S, Shamsizadeh A, Sepehri G. Effects of electrical stimulation of dorsal raphe nucleus on neuronal response properties of barrel cortex layer IV neurons following long-term sensory deprivation. Neurosci Bull. 2010;26(5):388-394.

64. Liu S, Bubar MJ, Lanfranco MF, Hillman GR, Cunningham KA. Serotonin $2 \mathrm{C}$ receptor localization in GABA neurons of the rat medial prefrontal cortex: implications for understanding the neurobiology of addiction. Neuroscience. 2007;146(4):1677-1688.

65. Han M, Huang XF, du Bois TM, Deng C. The effects of antipsychotic drugs administration on 5-HT1A receptor expression in the limbic system of the rat brain. Neuroscience. 2009;164(4):1754-1763.

66. Lian J, Huang XF, Pai N, Deng C. Effects of olanzapine and betahistine co-treatment on serotonin transporter, 5-HT2A and dopamine D2 receptor binding density. Prog Neuropsychopharmacol Biol Psychiatry. 2013;47:62-68.

67. Lian J, Huang XF, Pai N, Deng C. Chronic betahistine co-treatment reverses olanzapine's effects on dopamine D2 but not 5-HT2A/2C bindings in rat brains. Prog Neuropsychopharmacol Biol Psychiatry. 2015;56:75-80. 
68. Paxinos G, Watson C. The Rat Brain in Stereotaxic Coordinates. 6th edition. London: Elsevier; 2007.

69. Kusumi I, Takahashi Y, Suzuki K, Kameda K, Koyama T. Differential effects of subchronic treatments with atypical antipsychotic drugs on dopamine D2 and serotonin 5-HT2A receptors in the rat brain. $J$ Neural Transm. 2000;107(3):295-302.

70. Tarazi FI, Zhang K, Baldessarini RJ. Long-term effects of olanzapine, risperidone, and quetiapine on serotonin $1 \mathrm{~A}, 2 \mathrm{~A}$ and $2 \mathrm{C}$ receptors in rat forebrain regions. Psychopharmacology. 2002;161(3):263-270.

71. Huang XF, Han M, Zavitsanou K, Deng C. Olanzapine differently affects 5-HT2a and 2c receptor mRNA expression in the rat brain. Behav Brain Res. 2006;171:355-362.

72. DeLeon A, Patel NC, Lynn Crismon M. Aripiprazole: a comprehensive review of its pharmacology, clinical efficacy, and tolerability. Clin Ther. 2004;26(5):649-666.

73. Barnes NM, Sharp T. A review of central 5-HT receptors and their function. Neuropharmacology. 1999;38(8):1083-1152.

74. Hannon J, Hoyer D. Molecular biology of 5-HT receptors. Behav Brain Res. 2008;195(1):198-213.

75. Mora PO, Netto CF, Graeff FG. Role of 5-HT2A and 5-HT2C receptor subtypes in the two types of fear generated by the elevated T-maze. Pharmacol Biochem Behav. 1997;58(4):1051-1057.

76. Bortolozzi A, Díaz-Mataix L, Toth M, Celada P, Artigas F. In vivo actions of aripiprazole on serotonergic and dopaminergic systems in rodent brain. Psychopharmacology. 2007;191(3):745-758.

77. Abi-Dargham A, Laruelle M, Aghajanian GK, Charney D, Krystal J. The role of serotonin in the pathophysiology and treatment of schizophrenia. J Neuropsychiatry Clin Neurosci. 1997;9(1):1-17.

78. Berumen LC, Rodriguez A, Miledi R, Garcia-Alcocer G. Serotonin receptors in hippocampus. Scientific WorldJournal. 2012;2012:15.

79. Correll CU. From receptor pharmacology to improved outcomes: individualising the selection, dosing, and switching of antipsychotics. Eur Psychiatry. 2010;25(suppl 2):S12-S21.

80. Kesby JP, Cui X, Burne THJ, Eyles DW. Altered dopamine ontogeny in the developmentally vitamin D deficient rat and its relevance to schizophrenia. Front Cell Neurosci. 2013;7:111.

81. Karl T, Duffy L, O'Brien E, Matsumoto I, Dedova I. Behavioural effects of chronic haloperidol and risperidone treatment in rats. Behav Brain Res. 2006;171(2):286-294.

82. Dunlop BW, Nemeroff CB. The role of dopamine in the pathophysiology of depression. Arch Gen Psychiatry. 2007;64(3):327-337.

83. de Oliveira AR, Reimer AE, Brandão ML. Role of dopamine receptors in the ventral tegmental area in conditioned fear. Behav Brain Res. 2009; 199(2):271-277.

84. Biojone C, Casarotto PC, Resstel LB, Zangrossi H, Guimarães FS, Moreira FA. Anti-aversive effects of the atypical antipsychotic, aripiprazole, in animal models of anxiety. J Psychopharmacol. 2011;25(6): 801-807.

85. Meltzer HY, Li Z, Kaneda Y, Ichikawa J. Serotonin receptors: their key role in drugs to treat schizophrenia. Prog Neuropsychopharmacol Biol Psychiatry. 2003;27(7):1159-1172.
86. Klomp A, Václavů L, Meerhoff GF, Reneman L, Lucassen PJ. Effects of chronic fluoxetine treatment on neurogenesis and tryptophan hydroxylase expression in adolescent and adult rats. PLoS One. 2014;9(5): e97603.

87. Andersen SL, Navalta CP. Annual research review: new frontiers in developmental neuropharmacology: can long-term therapeutic effects of drugs be optimized through carefully timed early intervention? J Child Psychol Psychiatry. 2011;52(4):476-503.

88. Mazer C, Muneyyirci J, Taheny K, Raio N, Borella A, WhitakerAzmitia P. Serotonin depletion during synaptogenesis leads to decreased synaptic density and learning deficits in the adult rat: a possible model of neurodevelopmental disorders with cognitive deficits. Brain Res. 1997;760(1-2):68-73.

89. Zhang L, Ma W, Barker JL, Rubinow DR. Sex differences in expression of serotonin receptors (subtypes 1A and 2A) in rat brain: a possible role of testosterone. Neuroscience. 1999;94(1):251-259.

90. Gogos A, Kwek P, van den Buuse M. The role of estrogen and testosterone in female rats in behavioral models of relevance to schizophrenia. Psychopharmacology. 2012;219(1):213-224.

91. Bethea CL, Pecins-Thompson M, Schutzer WE, Gundlah C, Lu ZN. Ovarian steroids and serotonin neural function. Mol Neurobiol. 1998; 18(2):87-123.

92. Ladosky W, Gaziri LCJ. Brain serotonin and sexual differentiation of the nervous system. Neuroendocrinology. 1970;6(3):168-174.

93. Gogos A, Kwek P, Chavez C, van den Buuse M. Estrogen treatment blocks 8-hydroxy-2-dipropylaminotetralin- and apomorphine-induced disruptions of prepulse inhibition: involvement of dopamine D1 or D2 or serotonin 5-HT1A, 5-HT2A, or 5-HT7 receptors. J Pharmacol Exp Ther. 2010;333(1):218-227.

94. Cyr M, Bossé R, Di Paolo T. Gonadal hormones modulate 5-hydroxytryptamine2A receptors: emphasis on the rat frontal cortex. Neuroscience. 1998;83(3):829-836.

95. Sumner BEH, Fink G. Effects of acute estradiol on 5-hydroxytryptamine and dopamine receptor subtype mRNA expression in female rat brain. Mol Cell Neurosci. 1993;4(1):83-92.

96. Sumner BEH, Fink G. Estrogen increases the density of 5-hydroxytryptamine2a receptors in cerebral cortex and nucleus accumbens in the female rat. J Steroid Biochem Mol Biol. 1995; 54(1-2):15-20.

97. Borgkvist A, Malmlöf T, Feltmann K, Lindskog M, Schilström B. Dopamine in the hippocampus is cleared by the norepinephrine transporter. Int J Neuropsychopharmacol. 2012;15(4):531-540.

98. Guiard BP, El Mansari M, Blier P. Cross-talk between dopaminergic and noradrenergic systems in the rat ventral tegmental area, locus ceruleus, and dorsal hippocampus. Mol Pharmacol. 2008;74(5):1463-1475.

99. Uzun S, Kozumplik O, Mimica N, Folnegovic-Smalc V. Aripiprazole: an overview of a novel antipsychotic. Psychiatr Danub. 2005;17(1-2): $67-75$.
Neuropsychiatric Disease and Treatment

\section{Publish your work in this journal}

Neuropsychiatric Disease and Treatment is an international, peerreviewed journal of clinical therapeutics and pharmacology focusing on concise rapid reporting of clinical or pre-clinical studies on a range of neuropsychiatric and neurological disorders. This journal is indexed on PubMed Central, the 'PsycINFO' database and CAS,

\section{Dovepress}

and is the official journal of The International Neuropsychiatric Association (INA). The manuscript management system is completely online and includes a very quick and fair peer-review system, which is all easy to use. Visit http://www.dovepress.com/testimonials.php to read real quotes from published authors. 